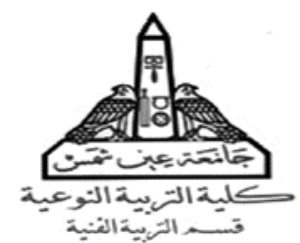

" دراسة التناقض كقيمة جمالية بين فن التراث وإلفن الحديث "

"Studying Contradiction as an aesthetic value and its impact on the art " of heritage and Modern art "

$$
\begin{aligned}
& \text { إعداد } \\
& \text { أ.م.د / أمل محمد حلمي يوسف إعاد } \\
& \text { أستاذ التذوق وتاريخ الفن المساعد - قسم التربية الفنية } \\
& \text { كلية التربية النوعية - جامعة عين شمس المساع }
\end{aligned}
$$




\section{مقدمة :}

" التتاقض " قد تتردد هذه الكلمة لثوان ، لساعات ، وحتي لأيام ، حيث تلتف في دوامة لا بداية لها ولا نهاية ـ ونحاول

$$
\text { الإجابة علي هذه التناقضات وإيجاد حل لها . }
$$

والتتاقضات موجودة كلياً في حياتتا ـ فليس ثمة شيء ليس به تتاقض ، ولولا التتاقض لما وجد شيء . وقد قال هيجل : " أن التتاقض هو جوهر جميع الظواهر والأشياء وهذا النضال هو منبع كل نمو" ـ وقد استخدمنا فلسفة التتاقض كقيمة جمالية للدراسة بين فن التراث والفن الحديث في مجال الفن التشكيلي وعلي سبيل المثال يمكننا

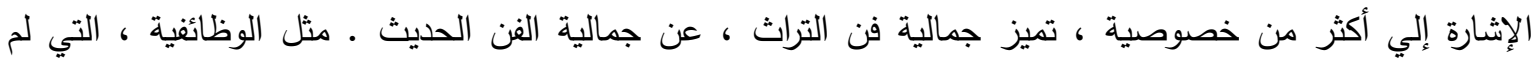

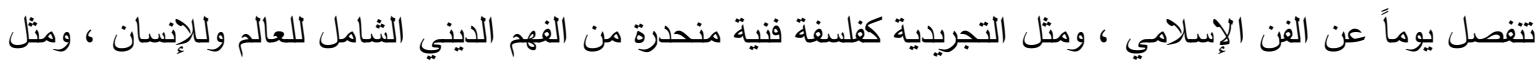
الغاء مبدأ المحاكاة كمبدأ فني جوهري ، ومثل الغاء الذاتية والفردية ، كمصادر من مصادر الفن الكبرى ، ومثل الوحدة في الأساليب . وقد يتصور البعض أن الأفكار واحدة لا تتفص ، فالبعض يري أن كل فكرة تتواجد بالتمام وبالضبط بعقل الآخر ، هذا

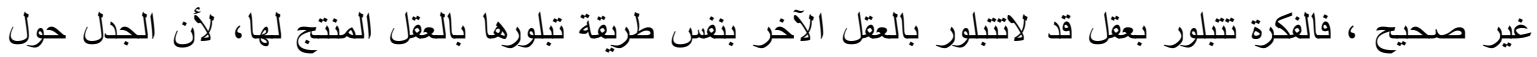

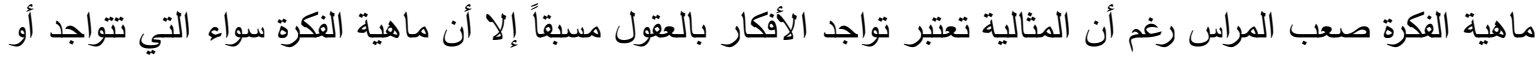

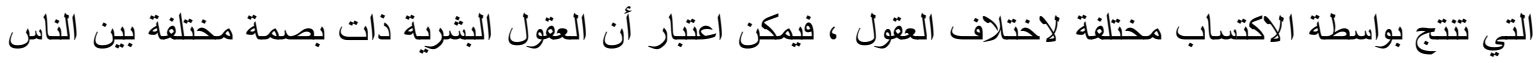
مثل بصمة الابهام أو بصمة العين فهنا اعتبر أن العقول تختلف بين كل اثثين من البشر وإن تثابهت في أجزاء كثيرة

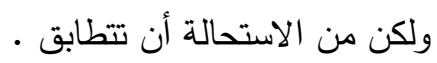

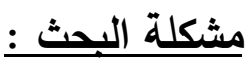

وتتلخص مشكلة البحث في التساؤلات الآتية : • ما هي فكرة التتاقض ، وآراء الفلاسفة والعلماء فيه ؟

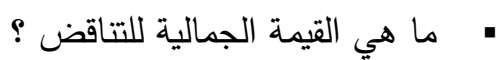

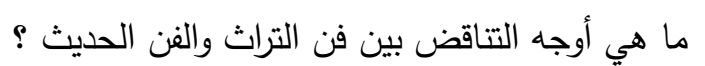
فرض البحث :

يفترض البحث أن للتناقض دوراً في تثكيل أسلوب فن التراث " الفن الإسلامي " والفن الحديث كما أنها تتعكس علي

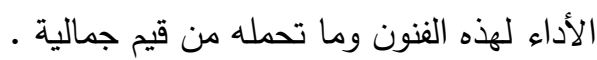

أهداف البحث : أهده:

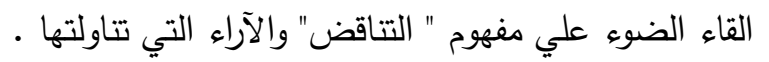

تعريف التتاقض في الفن التشكيلي •

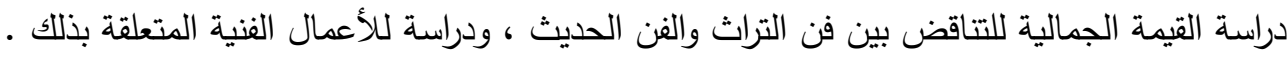

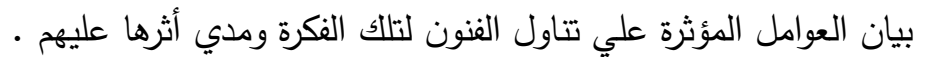

أهمية البحث :

• الاستفادة من التناقض كقيمة جمالية وتتعكس علي أسلوب فن التراث " الفن الإسلامي " والفن الحديث . 
دراسة وتعريف لمفهوم التناقض والآراء عنها .

" التعرف علي التتاقض في الفن التشكيلي وما قيمته الجمالية .

دراسة أوجه التناقض بين فن التراث والفن الحديث .

دراسة وتحليل مجموعة مختارة من الأعمال الفنية في الفن الإسلامي والفن الحديث لإيضاح فكرة التتاقض بين

• المرحلتان

\section{منهمية البحث}

يتبع البحث المنهج الوصفي التحليلي ويتبع الخطوات الآتية : • دراسة مفهوم التتاقض عامة ولدي الفن التشكيلي

• القاء الضور علي أوجه التتاقض بين فن التراث ( الفن الإسلامي ) والفن الحديث . • التحليل الفني والجمالي لمجموعة مختارة من الأعمال الفنية لإثبات فكرة التناقض بين الفنين .

\section{معني كلمة التناقض في اللغة العربة :}

مصد التناقض : هو التخالف والتعارض • (v) تتاقض تتاقضاً ( نقض )

( ) القولان أو العملان : اختلفا أو تعارضا .

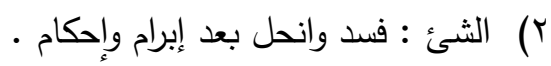

r) البائع والمشتري البيع : نقضاه ، أبطلاه .

ع) الشاعران : قال أحدهما قصيدة يعارض بها قصيدة الآخر .

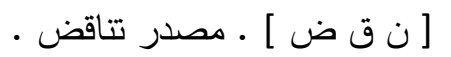

في كلامه تتاقض ، فهو لا يثبت علي رأي : تخالف ، تعارض ، تباين • (1 )

تعربف التناقض :

هو مفهوم يشير إلي العناصر المتضادة والمؤتلفة التي تكون حقيقة الشيء أو الموضوع ، وهذه العناصر تتداخل في علاقة ضمن آلية واقعة ، أي أنها تحتوي جانبين متضادين يتعلق أحدهما بالآخر ، فبنية الشيء ما هي إلا مجموعة علاقات تشكل " التتاقضات " . ولا يقتصر مفهوم الجوانب المتضادة في الثيء علي الربط أو العلاقة فيما بينها ، وإنما يرتفع إلي مستوي الوحدة ، أي أن الثيء هو (وحدة تتاقضات) وتلك الوحدة مصدر لحركة الثيء الداخلية وتطوره .

والتناقض يعني تلازم بين قضيتين يوجب صدق إحداهما وكذب الأخرى • والتتاقض هو القول بوجود شيء وعدم وجوده في وقت واحد وبمعني واحد ، وهو القول باجتماع صفتين في شخص واحد ، وهو القول إن أمراً ما صادق وكاذب معاً.

وقد عرف التتاقض المقصود هو أحد أقسام التقابل ولنضعه هنا بعبارة جامعة فنية بخصوص القضايا فنقول : (تتاقض القضايا) أي اختلاف في القضيتين يقتضي لذاته أن تكون احداهما صادقة والأخرى كاذبة . (r) 
قد نستخدم التتاقض والتضاد في لغتنا العادية بنفس المعني دون أن يلتبس الفهر ، فنقول مثلاً إن الليل والنهار متضادان أو متتاقضان ، كذلك نقول عن الأسود والأبيض.. وغيرهم.

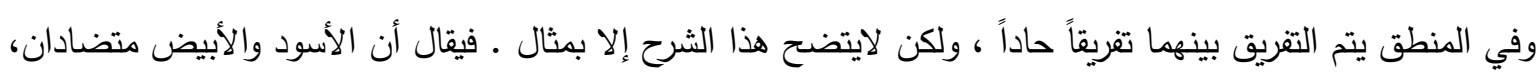

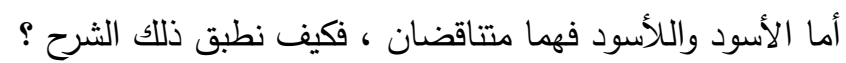
المتضادان : لايصدقان علي شيء واحد فمني هذا أن الثيء إذا كان أسود فلا يمكن أن يكون أبيض في نفس الوقت

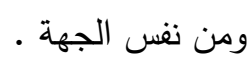
أما المتناقضان : فإذا صدقت احدي الصفتين علي شيء فالأخرى كاذبة حكماً ، الأسود واللأسود مثلاً لأنهما

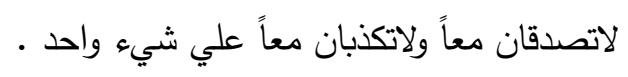
وليس هذا التفريق بين التتاقض والتضاد في المنطق فقط ، بل هو أسلوب في التفكير تتبعه عقولنا وتتكر من خلاله ،

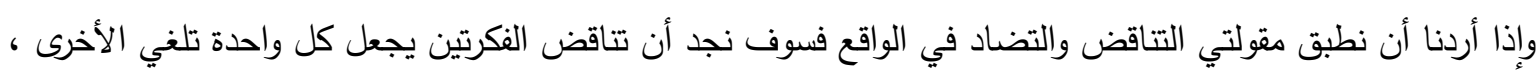

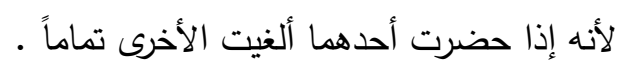
أما التضاد فالأمر مختلف إذ أن المتضادين يقبلان تبادل التأثير بين بعضهما بعضاً ، وتكون نتيجة هذا التأثير أن

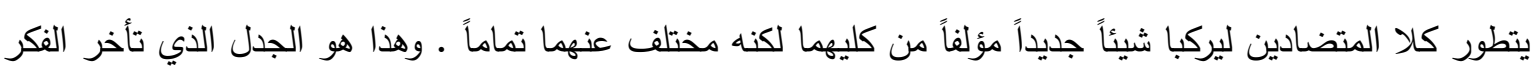
الفلسفي طويلاً حتي استطاع أن يكتشفه كمنهج في التنكير الكلي الذي يقود إلي تفسير الوجود وتطوره وحياة الإنسان

فيه. (r)

\section{تاربخ التناقض عند الفلاسفة :}

عرف " أفلاطون " التتاقض : بأنه الثيء نفسه لايمكن أن يفعل وينفعل في جزء واحد منه بطريقتين متضادتين في آن

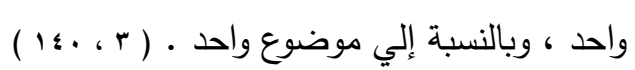

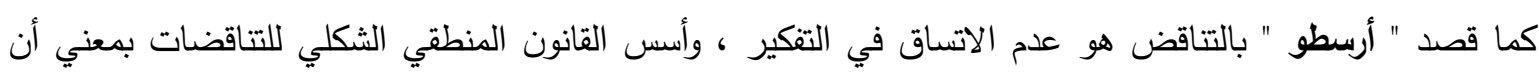

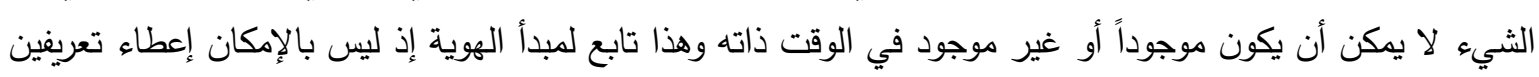

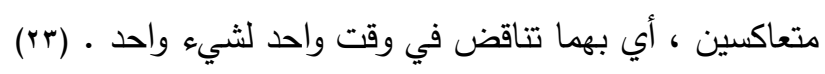

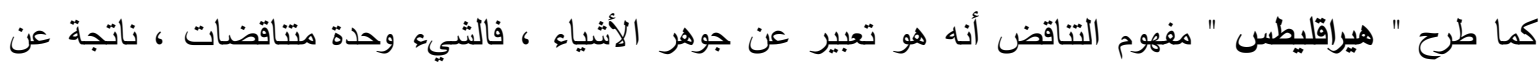

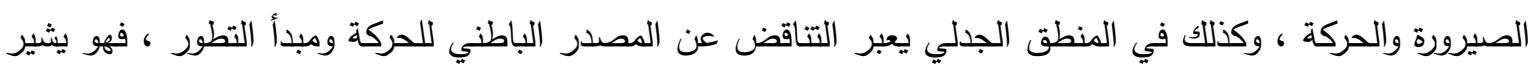

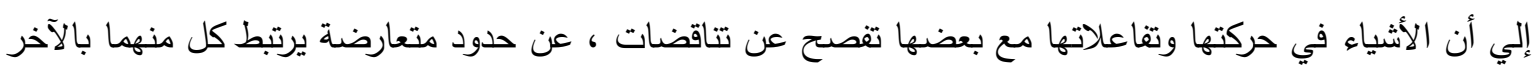

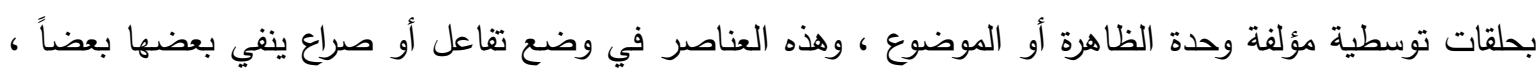

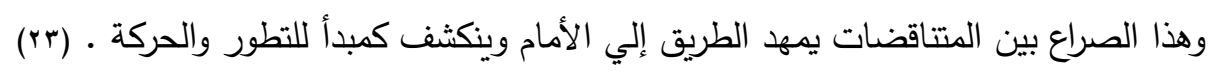

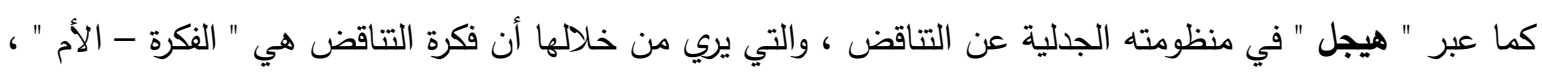
هو " جذر كل حركة وكل تظاهر حي ، فقط بقدر ما يحوي شيء من الأشياء تناقضاً ، يكون هذا الشيء قادراً علي

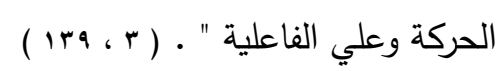

$$
\text { التناقض في الفنون : }
$$

الفن هو تعبير عن الفكرة والموضوع والعاطفة وانعكاس لمضمون بطريقة لا تخالف الخيال الفني ، إنها حالة مدركة تعبر عن الوجدان البشري وهو السبيل الوحيد للتعبير عن مكنونات الإنسان . 
وعندما نتكلم عن التتاقض في الفن فإننا نتكلم عن الحياة بصورتها الجميلة التي لايمكن الاستغناء عنها مهما كان فبدونه لايكون للحياة أي معني ولا حتي قيمة نتذكر بها كل شيء جميل ، أنه يعلم الإنسان الفكر الصحيح والإنسانية

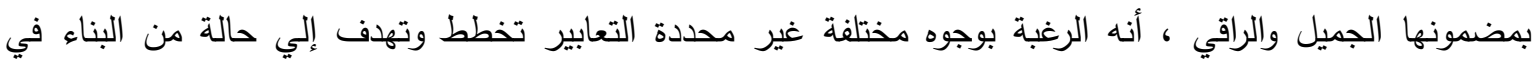
العلاقات الإنسانية من أجل إحداث وعي هام لمصير المجتمع ، لذا يقوم الفنان بحذف التناقضات الفكرية المستندة

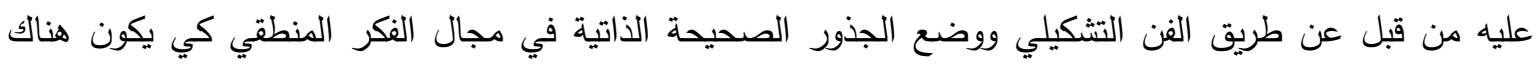
وضعاً يمكن الاعتماد عليه في تفسير الأشكال الأصلية وإنجاز الأعمال الفنية الواضحة والمتضمنة فئة بين الثكل

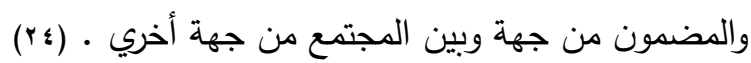
إذا سلمنا بأن الحديث صفة تتاقض القديم ، فالتقابل بين الحديث والقديم يفضي إلي تقسيم مستويات للزمان تبدأ بالماضي فالحاضر ثم المستقبل ـ غير أنه من الخطأ اعتبار صفة الحديث في مقابل القديم تشير علي الدوام إلي

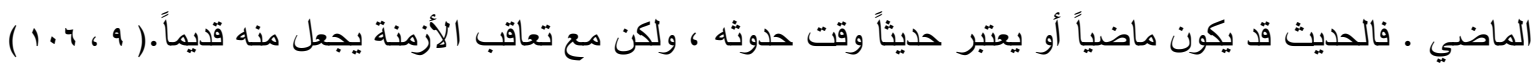

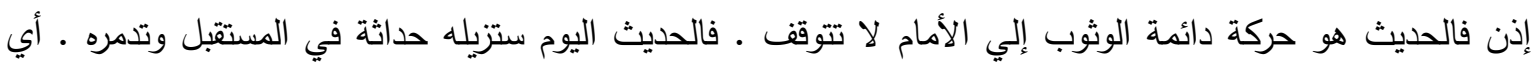
بمعني آخر أن الحداثة هي الفعل الخلاق للحياة النابع من داخلها. لذلك فهي لاتستمر علي حال ، وإنما دائمة الحركة

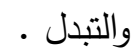

أما " التراث " فهو مصطلح يطلق علي مجموع الموروث البشري لنتاج الحضارات السابقة ، ومعناه في اللغة العربية "

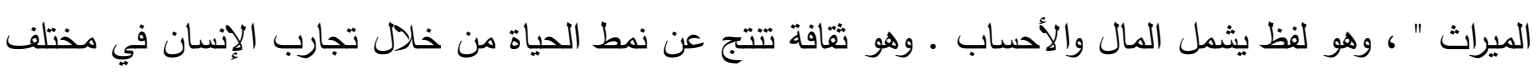
الميادين العلمية والحضارية ـ وهو الإرث الفكري والثقافي التي تركته الشعوب ، وقد وصل إلينا علي مر العصور

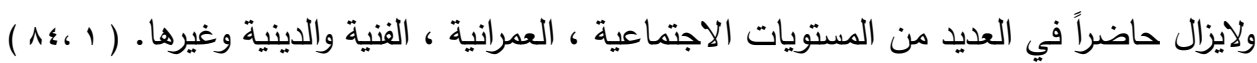

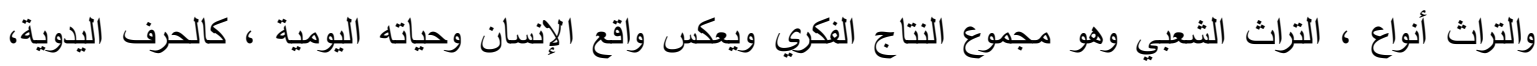
والأزياء والفنون الثعبية المختلفة ، وهو يعكس التطور الحضاري للمجتمع من الناحية الاقتصادية ، الاجتماعية ،

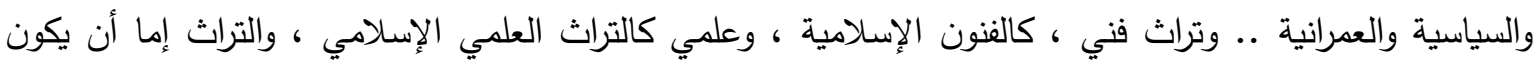
فاعلاً أو جامداً فقد أهميته مع التطور الحضاري الفكري ، أو ضاراً لاتقع فيه مثل فنون السحر والشعوذة وغيرهما .

وفي التتاقض بين فن التراث والفن الحديث نجد الوظائفية، التي لم تتفصل يوماً عن الفن الإسلامي ، ومثل التجريدية

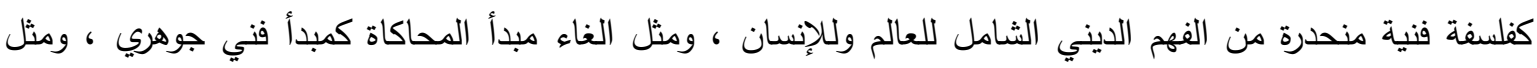

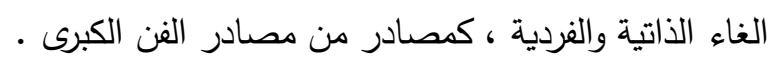
وعلي مدار العصور والأزمان الدختلفة منذ بداية الخليقة وحتي اليوم تتاقضت الموضوعات الفنية بشتي مجالاتها المتتوعة ، ففي الفترات الموغلة بالقدم تعرض الإنسان لتجربتي الجوع والثبع ، الخوف والأمان ، وهكذا مروراً بالكثير

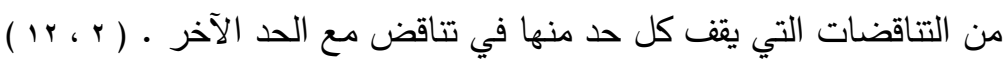
وبتتابع الأزمنة وانتقال الحضارات وتتاقض العصور مع بعضها البعض في الفكر والثقافة والظروف الاجتماعية، نتج

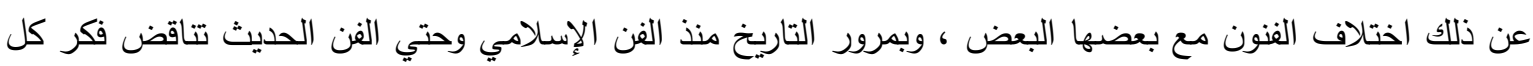

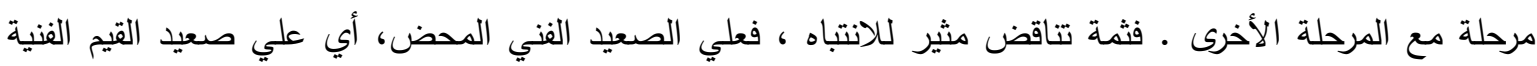

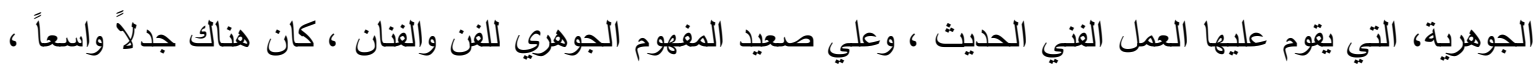
وتأملاً جمالياً عميقاً ، فثمة اختلاف يصل إلي حدود التتاقض الحاد بين القيم الفنية التي تقوم عليها اللوحة الحديثة ، وبين القيم الفنية التي قام عليها فن التراث. 
التراث في معاجم اللغة العربية وفي الأدب العلمي العربي هو " ماورثاه عن الأجداد " وأصلها من ورث يقول ابن منظور في لسان العرب المحيط ، ورثه ماله ومجده .

تعريف التراث :

فلا يوجد تعريف خاص بالتراث ولكن هناك تعريفات كثيرة عن علماء وكتاب التراث وبخاصة التعريف الذي قدمه "

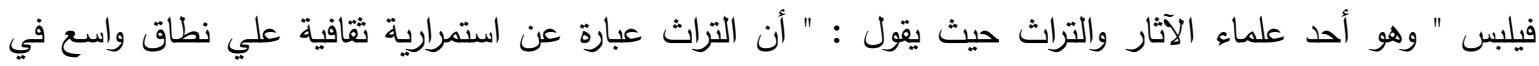
مجالي الزمان والمكان تتحدد علي أساس التشكيلات المستمرة في الثقافة الكلية وهي تشمل فترة زمنية طويلة نسبياً وحيزاً

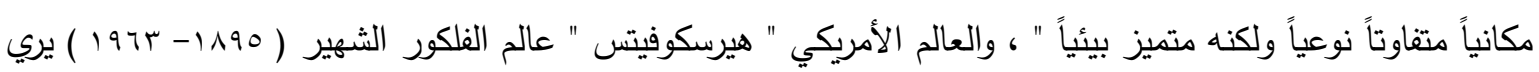

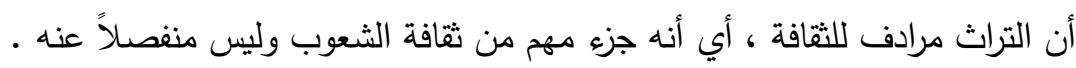

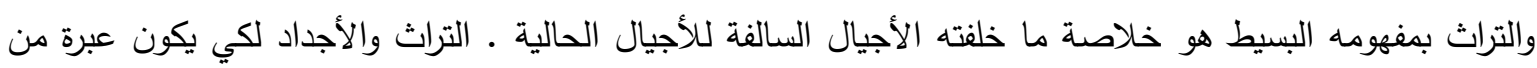

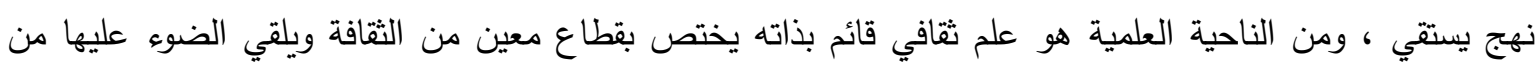
زوايا تاريخية وجغرافية واجتماعية ونفسية ـونهية

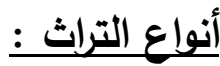

1- التراث الحضاري : هو ما خلفه لنا الأسلاف من تراث حضاري قديم مثل الآثار بكل أنواعها ويشمل التراث البابلي

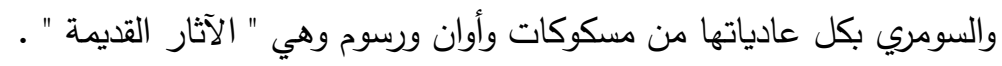

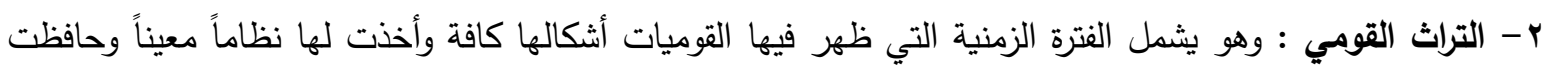

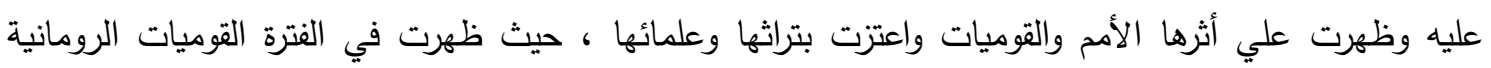

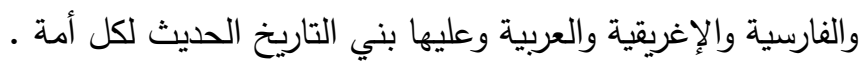
ب- التراث الثعبي : وهو مكمل للنوعين الحضاري والقومي ، حيث أصبحت لكل مجموعة أو بيئة صفاتها التي تتميز

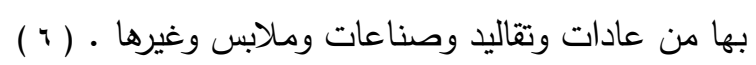

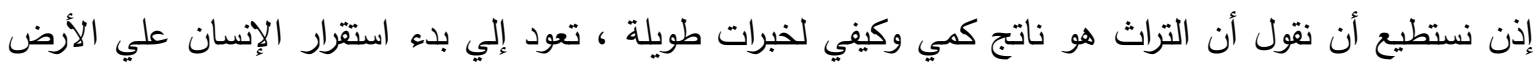

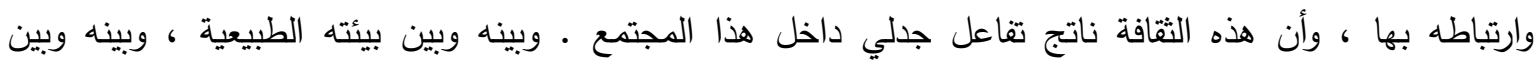

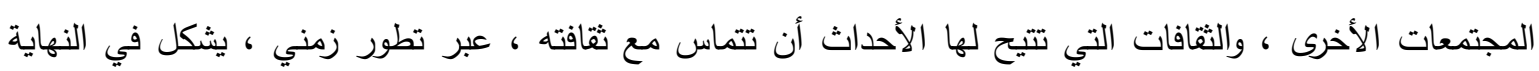

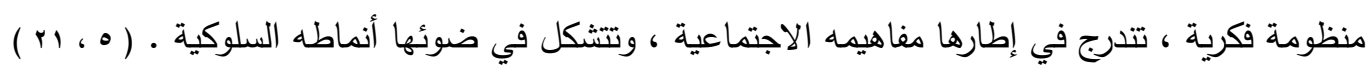

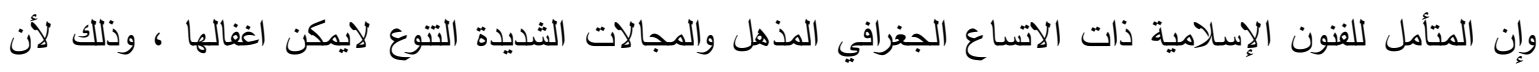
التراث الفني الإسلامي يعتبر مخزوناً لمنجزات الوعي الحضاري الإسلامي المتراكم عبر العصور في ذاكرة البشرية . الفن الحديث الفيث: لا يقصد بالفن الحديث هنا فن عصر تاريخي معين ، بقدر ما هي تدل علي شكل من الصياغة الفنية ، وتمثل اتجاهاً

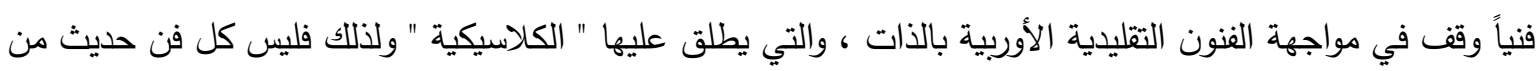

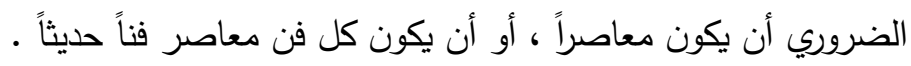

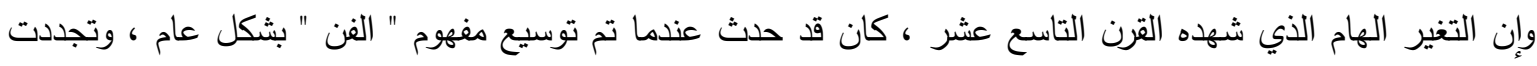


وكانت فكرة تتاول الفن الإسلامي كأحد جوانب التراث ، ودراسة القيم الجمالية فيه واتخاذه كمنطلق حضاري بخاصة

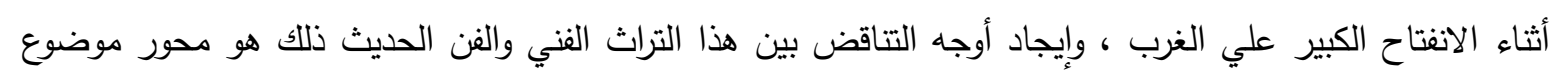
الدراسة.

\section{أوحه التناقض بين فن التراث والفن الحديث :}

ان الفن الاسلامي يتتاقض مع الفن المعاصر ، وإن كان يتناقض مع مسيرة الفن منذ عصر النهضة الأوربية ، حيث يبقي فن فنانين هم أسماء وعلامات واتجاهات ـ في حين يبدو لنا الفن الإسلامي كأنه فن بلا فنانين . والفن حافل بالمتاقضات ، ويتخذ بعداً ثقافياً في اطار الفكر التفكيكي • ويفهم أي بناء كلي علي أساس فئ تفكيكي

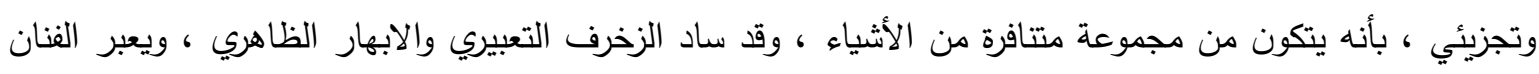

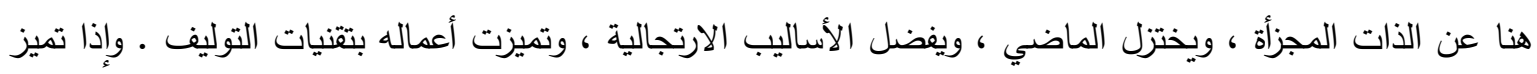

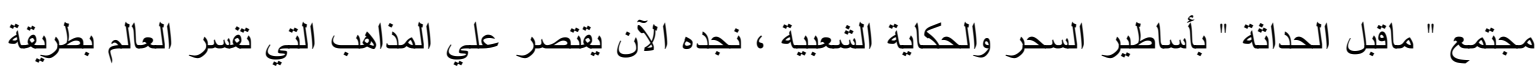

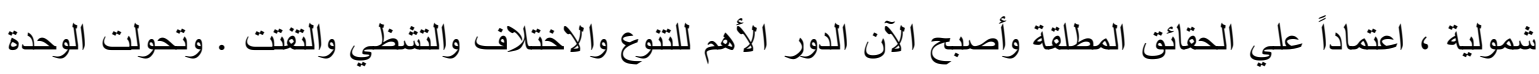

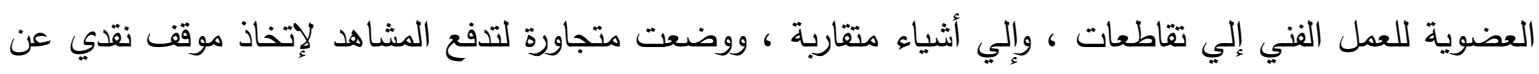
العالم الذي يعد يمثل كلية عضوية . وهكذا حل ( التفتيت ) محل ( الفردية ) وشاع الأسلوب القائم علي التعارض ، واستبدل أيضاً مفهوم المحاكاة بفكرة

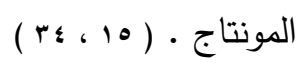

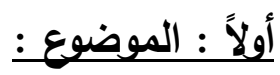

في الفن الإسلامي يسقط الموضوع كعنصر أساسي ، وكطرف جوهري من البنية الجمالية التي تقوم عليها ابداعية هذا

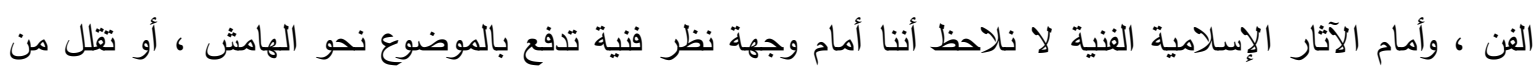

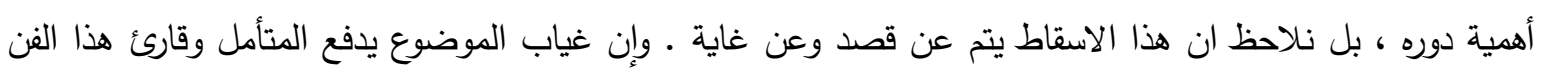

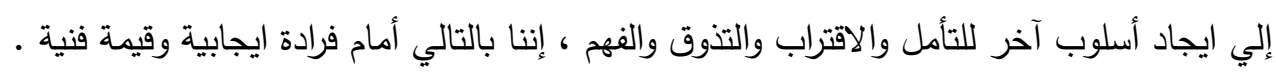

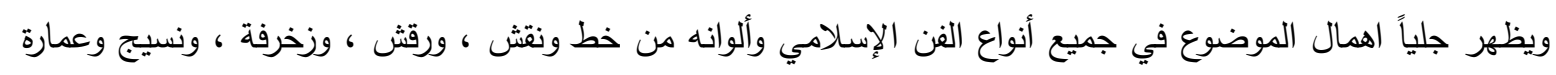

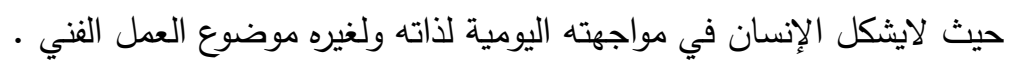

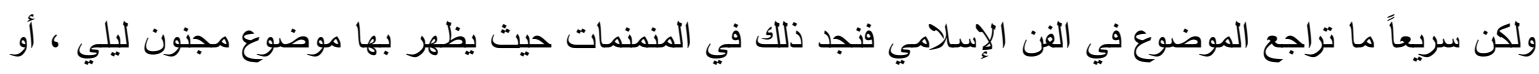

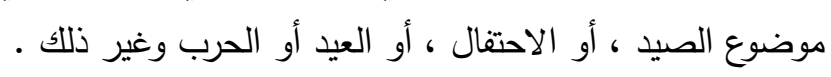
وعند تحليل " مجنون ليلي " ( شكل 1 ) الوصف : أبدعت مدرسة هراة في تصوير الأشعار بأسلوب عاطفي غنائي. وتميزت الرسوم بالأناقة والدقة التزينية ، وبالألوان القوية المنسجمة ونجد الديوان كتب أعلي وأسفل المنمنمة أما في

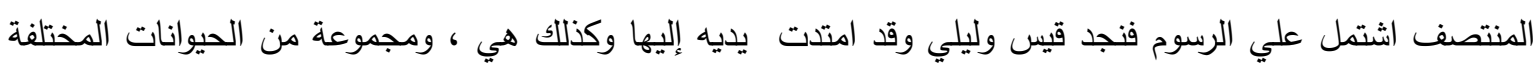
والنباتات

التحليل الفنيـ نجد القيم الحسية الجمالية في التصميم من حيث التماسك في توازن العلاقات بين الخطوط والألوان والنسب والسطوح وقد أدي ذلك إلي الترابط بين العلاقات الشكلية مع المعنوية في وحدة عضوية وبالتالي تدل علي

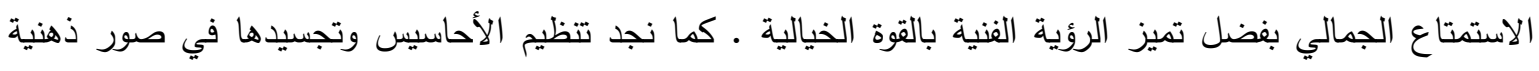

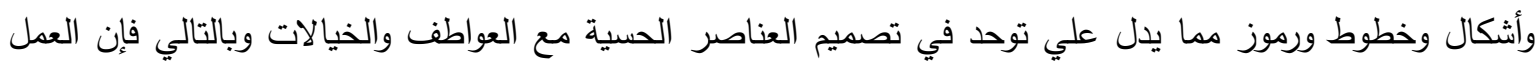

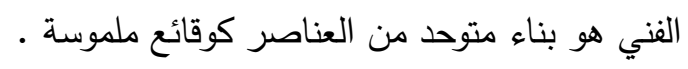


ونجد القيم الحسية الجمالية في التصميم من حيث التتوع في وجود العناصر الثكلية المتتوعة مما يدل علي الثراء

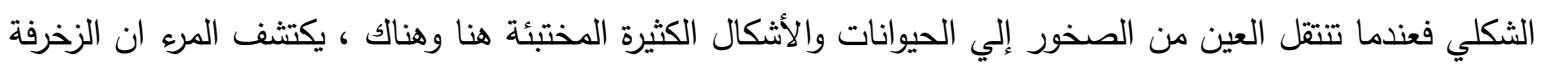

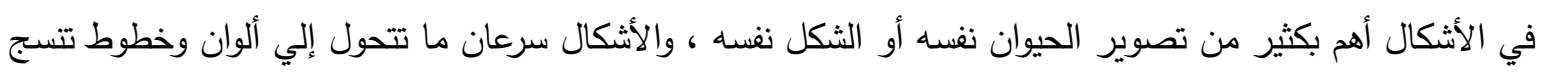
هذا النظام الخفي في مله المسافات والفراغات مما يقوي الإحساس بالبهجة الجمالية ـ كما نجد التضاد بين العالم

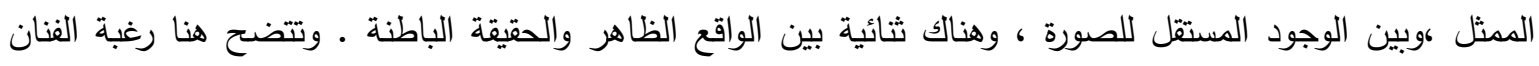

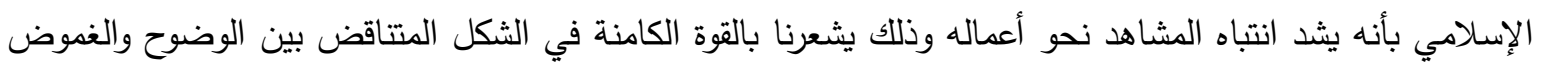

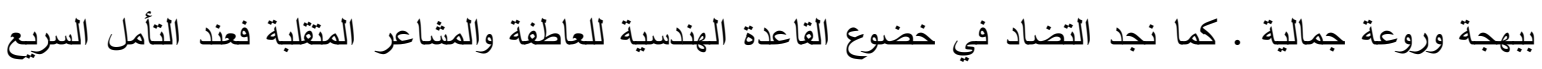
للأشجار في المنمنمة نجد أنها لا تحاكي الطبيعة ، بل هي أسلبة لها ومزيد من التأمل يكثف لنا أن هذه فئه الأشجار مرسومة بنظام هندسي يتكرر من جهة الأغصان التي تتقابل بطريقة نظامية دقيقة ومن هنا تتحول الأشجار لمجموعة

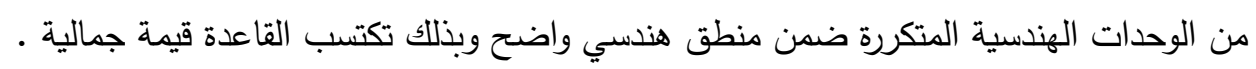
كما نجد البساطة في الأسلوب حيث الايقاعات الخطية بسيطة وغير مركبة حيث يعمل التبسيط علي سهولة استيعاب

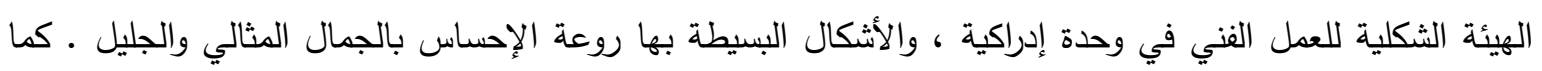

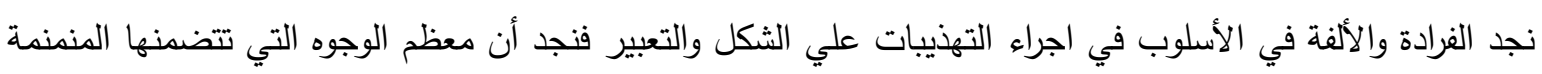

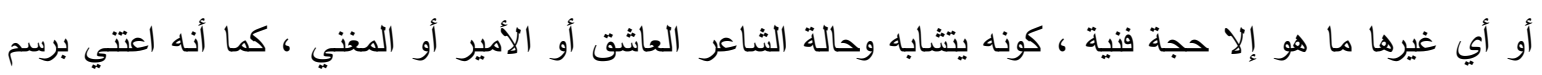

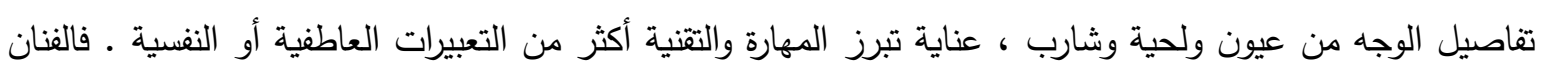
يقوم بتحسين الثكل والمعني في هيئة جمالية . ومن هنا نكتشف هكذا أن المنمنمة في تثكيلها الفني لا تكون تابعة للموضوع سواء موضوع هنئة فنون ليلي أو الصيد بل

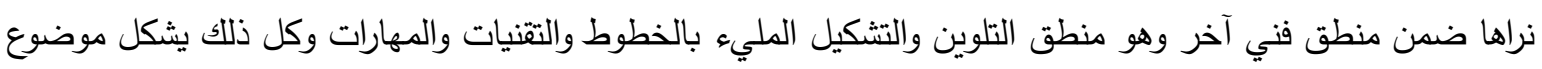

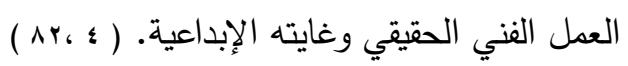
إذن كيف يمكن تقييم غياب الموضوع في الفن الإسلامي ، إنه ليس نقصاً في الرؤية الفنية ، أو هو من قبئه الإبيل الاهمال

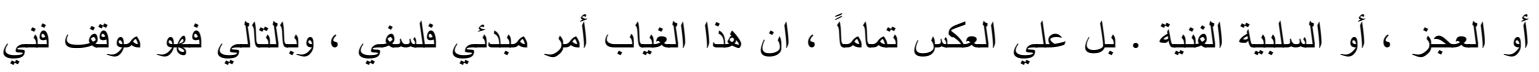
وجمالي المجال إن القاعدة الذهبية للإبداع في هذا الفن ، حيث تسقط عنها الموضوع كعنصر جوهري ، تقيم مكانه المبدأ . فتصبح

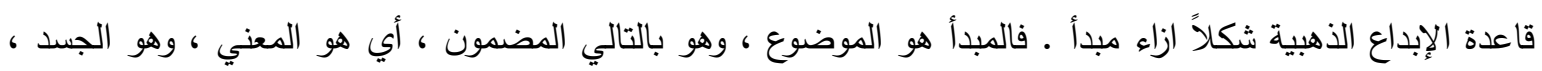

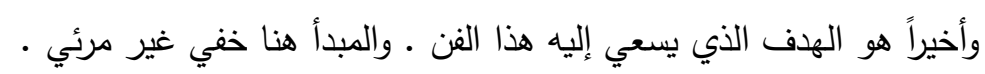

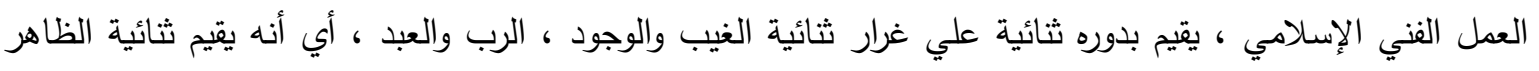

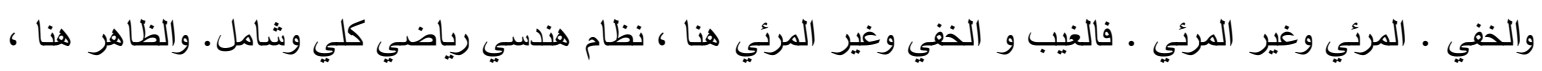

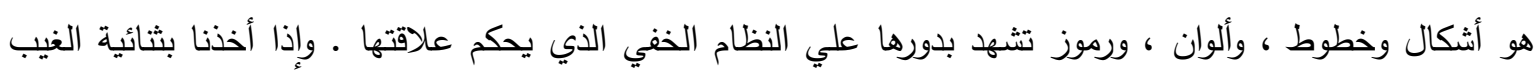
والوجود الدينية ، فإن المطلق في الفن الإسلامي هو غير المرائي ـ اي هو الثون النظام الهندسي الرياضي الذي يتحكم

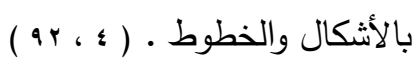
أما التتاقض ظهر في الفن الحديث فنجد أن الموضوع كانت له مكانة جوهرية، وربما المكانة الأولى في العمل الفنيّ الكلاسيكيّ بواقعيته المثالية أو النموذجية المستتدة إلى قيم اجتماعية محددة، هي قيم المجتمع الأرستقراطي (المسيطر) على السلطة والثروة، وصاحب الحق في فرض القيم والعقائد. فالموضوع له مكانة خاصة ، لا من حيث كونه غاية في حد ذاته ، ولكن باعتباره وسيلة لإثارة الفنان لكثف ولثفان المضامين

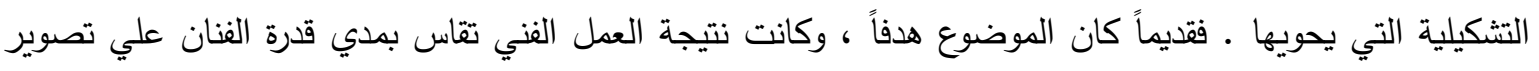


الموضوع ، بحيث يطابق في نهايته الصور البصرية التي حوله عادة . وقبل كثف الكاميرا كان تصوير الموضوع

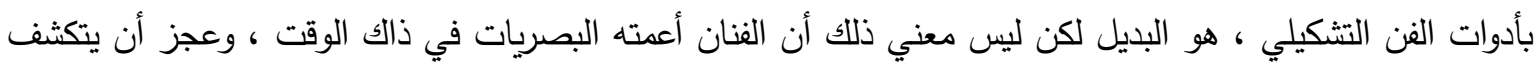

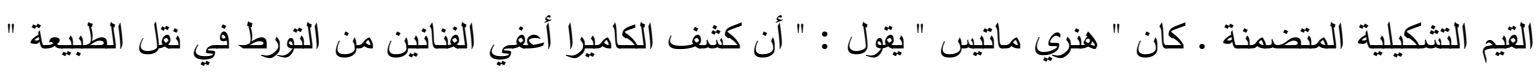
ولعله يثير هنا إلي الأعداد الهائلة من المصورين الذين كانوا يرون أن الفن هو الطبيعة ، ولم يدركوا أنه النظام

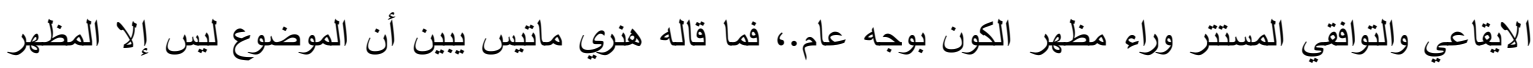

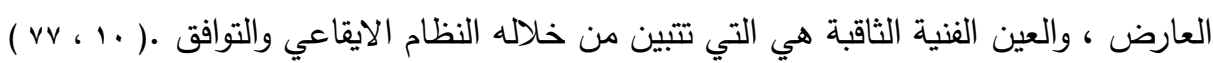

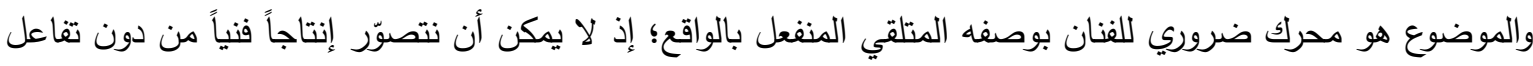

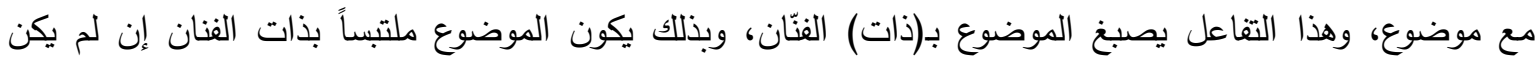

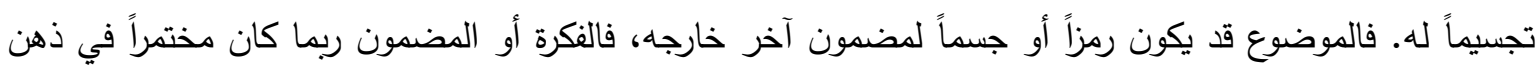
المبدع إلى الوقت الذي التقى فيه المبدع بالمثير المناسب، الذي حرّكه وساهم في إخراجه إلى الوجود، ولكن تظلّ الفكرة

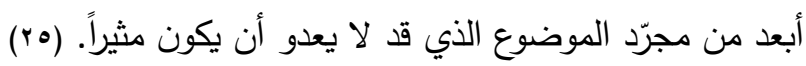

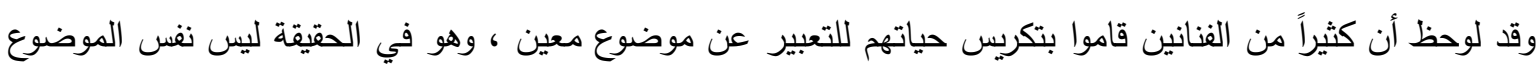

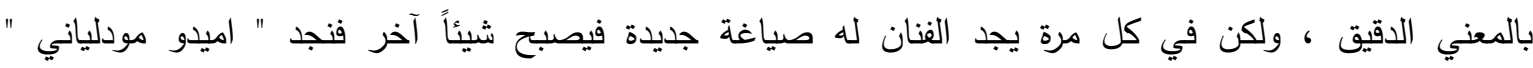
الهتم بالوجوه والرسوم النصفية لشخصياته ـ ( A. Modigliani

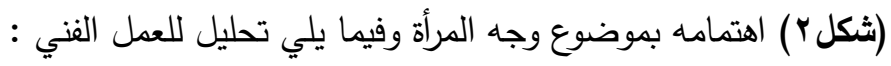
الوصف : هي لوحة لامرأة جالسة علي كرسي وهي تبعد عن الواقع في شكلها وتتميز بالنبل والأصالة ، كما أنها تتميز

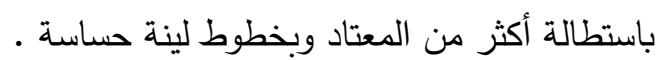

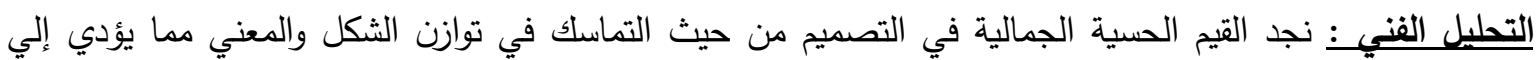
ترابط العلاقات في وحدة عضوية ـ ونجد التماسك في تميز التصميم بصيغة شكلية سائدة رغم تضمنه لأفكار عديدة

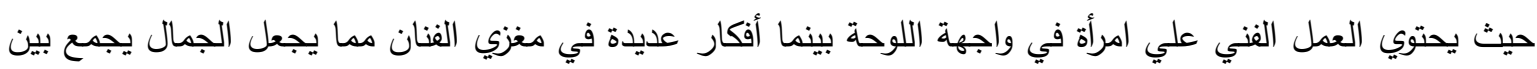

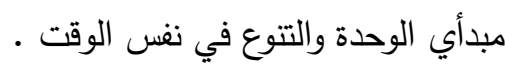
كما نجد التتاقض بين الوضوح والغموض في اللوحة حيث نجد صورة لامرأة هذا الواضح أما الغامض ما هو؟ مها يؤدي إلي القوة الشكلية والتعبيرية وهذا التتاقض يشعرنا ببهجة وروعة جمالية .

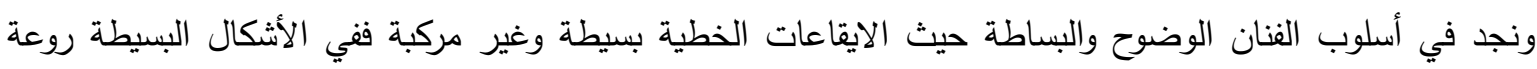
الاحساس بالجمال المثالي والجليل ـ كما نجد أن أسلوبه تميز بالفرادة حيث أخضع الرؤية الفنية وفق طريقة الفيه الفنان

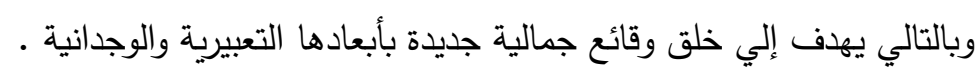
وقام الفنان بتحريف النسب مما يحقق التميز بفضل تمزيق العادة في الاستجابات البصرية والعاطفية والجميل في الفن بهابل بهابه

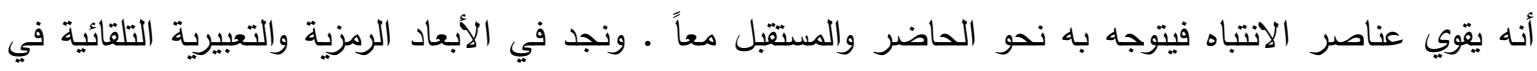

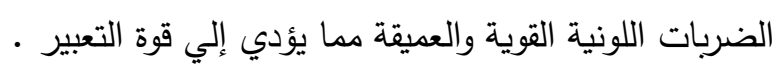

ثانيا : التجريـ :

ولنبدأ بالتجريد في الفن الإسلامي ، وعند تأملنا للفن الإسلامي ، نجد أن التجريد ليس تجريد الواقع من صفاته الظاهرة.

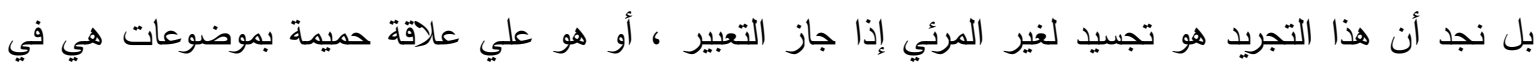

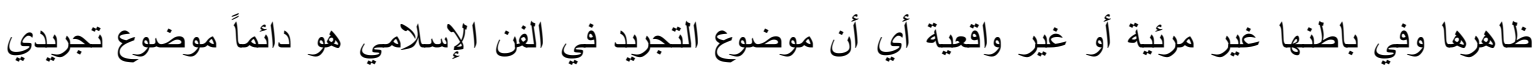

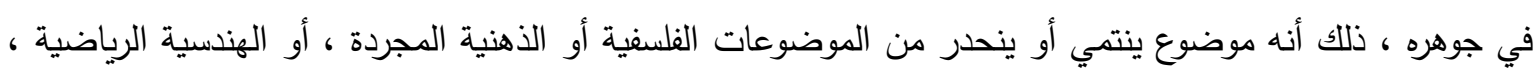

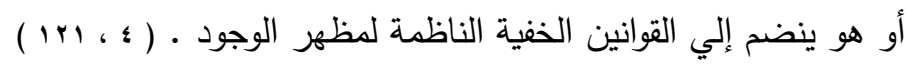


ويذكر بريون " أن الفن التجريدي كما يبدو لي أكثر قدرة من الفن التشبيهي علي التعبير عن روحانية عميقة وعالية ، لأنه لايرتبط بالثكل التشثيلي ، ولأنه أيضا يستطيع بدون وساطة هذا الثكل أن يثير مباشرة وحالاً حالات عاطفية

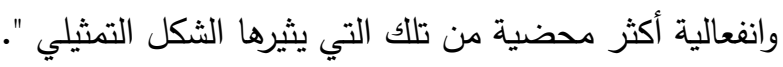
لذلك يتمثل التعبير الملازم للتفكير الروحاني والصوتي في الأشكال التجريدية أو في الرموز غير التشبيهية ـ وفي ذلك

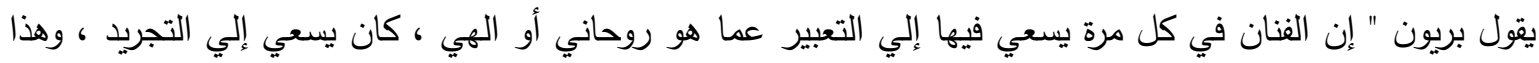

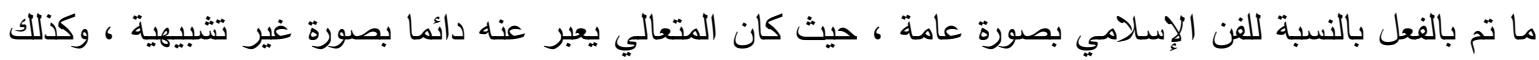

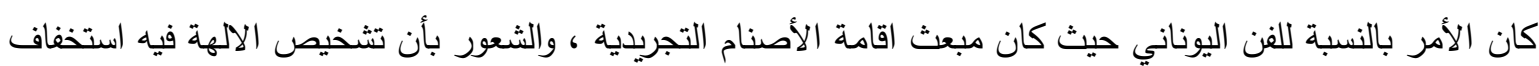

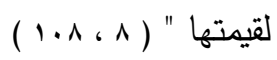
أما موضوع التجريد في الفن الحديث ، فهو في معظمه موضوع واقعي وملموس وموجود في الواقع أو الطبيعة، إذن

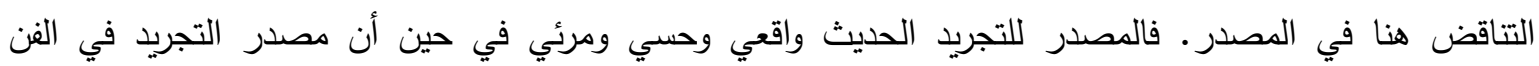
الإسلامي مصدر مجرد غير واقعي وغير مرئي . وفي التجريدية الحديثة من الواضح أن النزعة إلي عدم التشبيه لم يكن مصدرها الإني الارتباط المتعالي الوحداني ، ولكن بالمتعالي المطلق ـ هذا الارتباط الذي تم نتيجة انفعال داخلي عميق عاني فيه الفنان كثيراً من الأخيلة ، وأبصر كثيراً من الرؤي الغامضة التي تكثفت له علي شكل مساحات وبقع لونية وخطوط مطلقة من أي قيد واقعي .

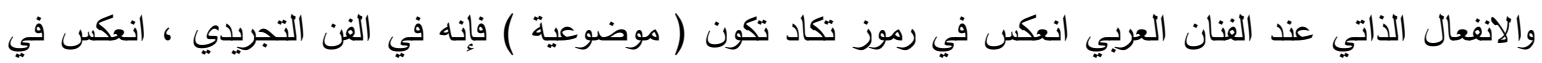

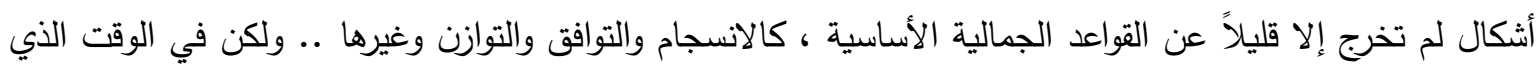

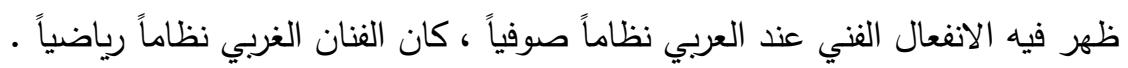

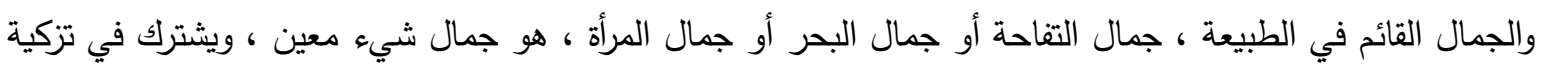

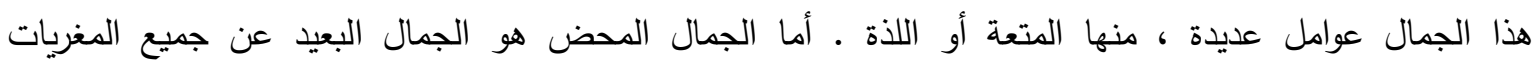
الاضافية، فلا وجود له في الطبيعة ، إذ نادراً ما نعجب بزاوية من جدار مهترئ كسته طبقة من العفن ، اللهم إلا إذا

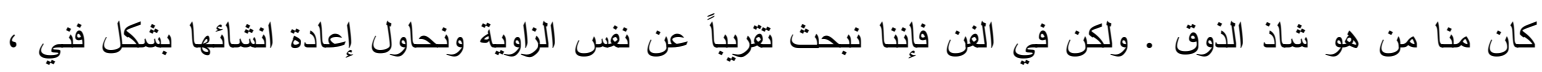

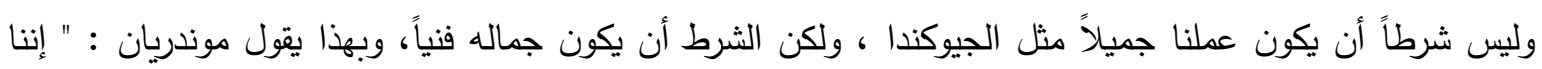
نسعي وراء جمالية جديدة محضة ، خطوط وألوان محضة ، ذلك لأن العلاقات المحضة هي وحدها القادرة علي

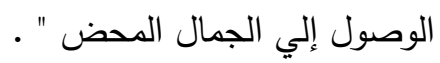
والفن الإسلامي حتي وقت قريب كان يعتبر مجرد تزيين لامضمون له ، ومع ظهور الفن التجريدي أصبح الرقش

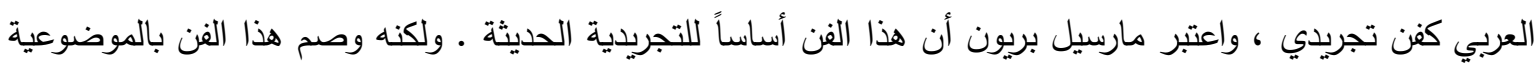

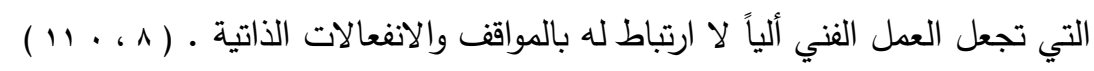

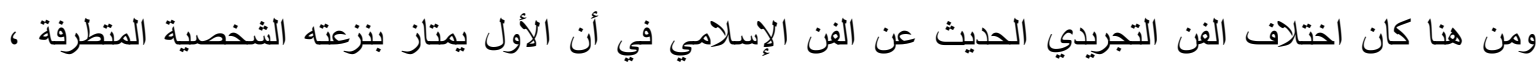

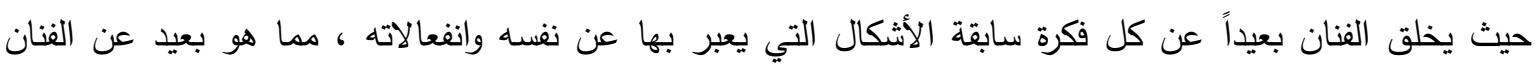

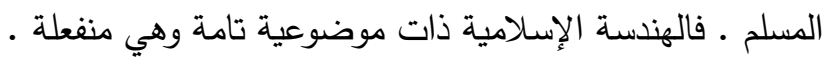
ومن هنا استطاع الأستاذ " بريون " أن يوجد فرقاً واسعاً بين هندسية موندريان ، وهي هئهي هندسية شخصية محضة، وبين

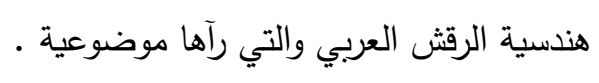

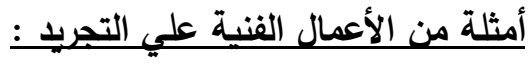

في الفن الإسلامي ( شكل r ) الوصف : جانب من سقف خشبي مؤلف من نجوم سداسية ، وثمانية ملونة ومذهبة من

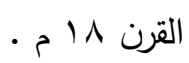


التحليل الفنيـ : نجد القيم الحسية الجمالية في التصميم والتكوين من حيث التماسك في تكرار النموذج في أوضاع

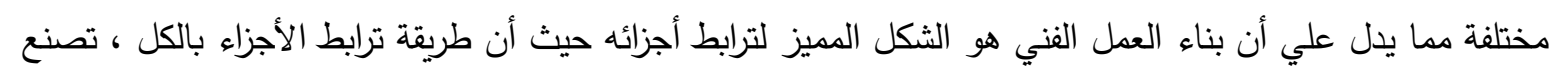

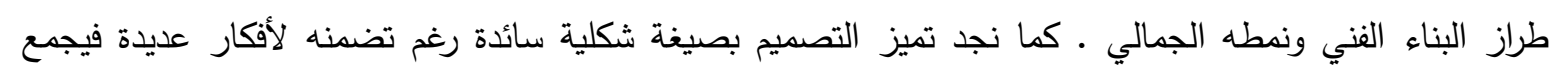

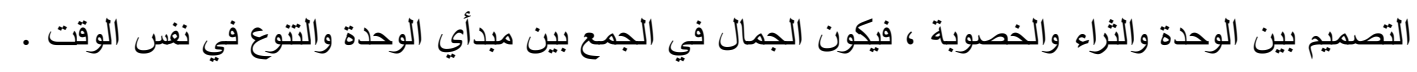

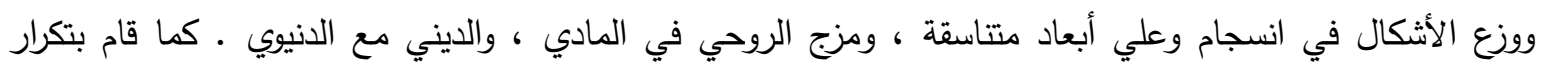

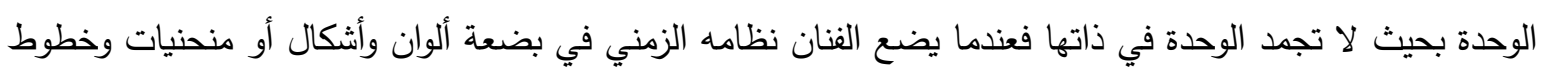

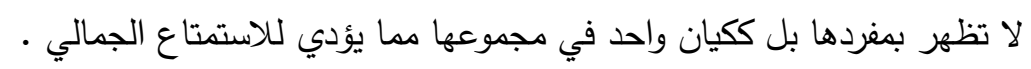

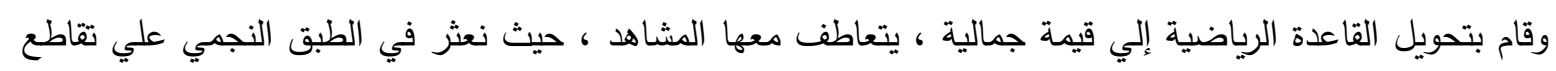

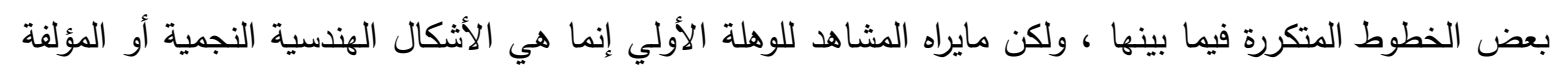

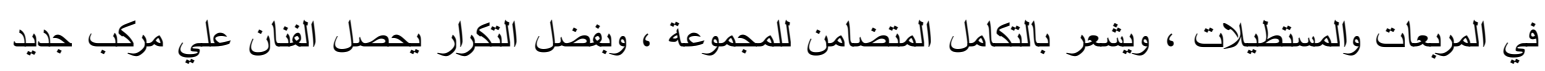

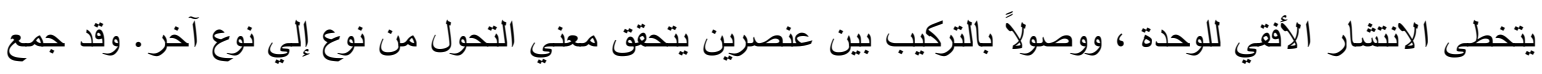

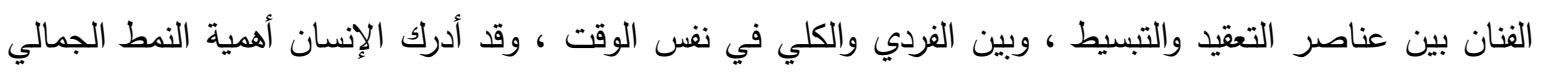

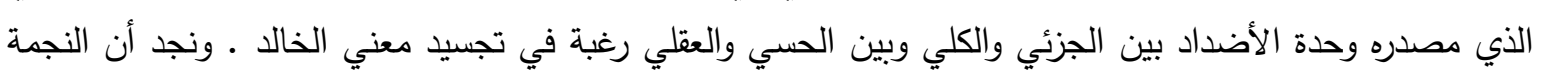

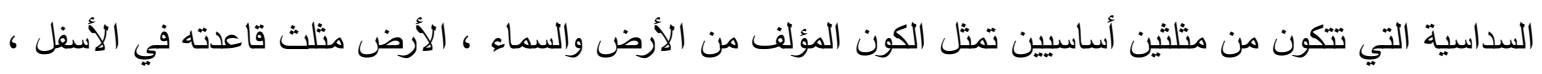

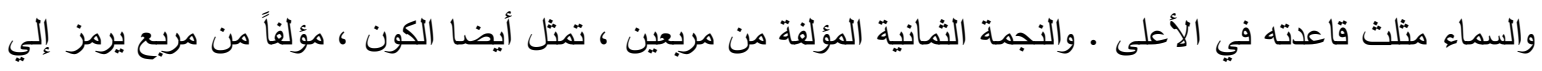

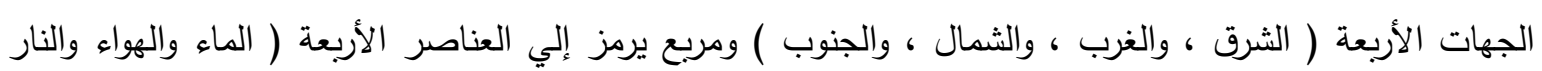
والتراب )

إذن لقد تحقق في هذه الصور الانسجام بين المتناقضات واستطاع الفنان أن يصل إلي مبدأ التوحد ، الذي ليس للتتوع

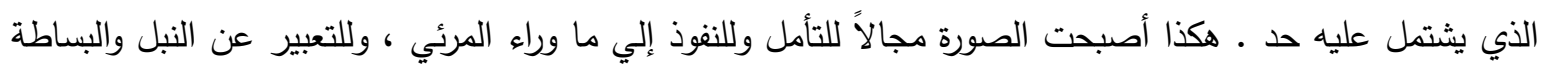
والشاعرية . و الله هو الكون وهو الحق وهو الزمن وهو الوجود ، والمصور هنا يعيش في المناخ الكوني الإلهي ، ليس لأنه يصلي

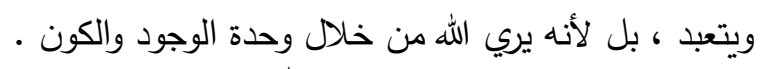

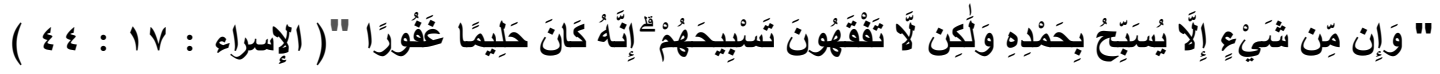
وفي الفن الحديث فنجد " موندريان " Piet Mondrian وهو فنان هولندي أقام مدرسته المسماة " التشكيلية المحدثة " علي تمحيص عقلي رياضي في محاولة لتعرية الأشياء عن شيئيتها ، دافعاً بها إلي أعمق أبعاد التعرية ــ واستخدم

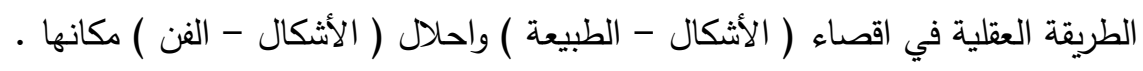

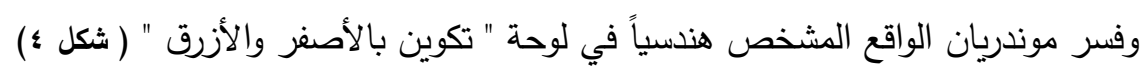

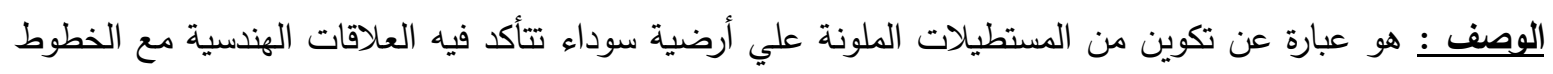

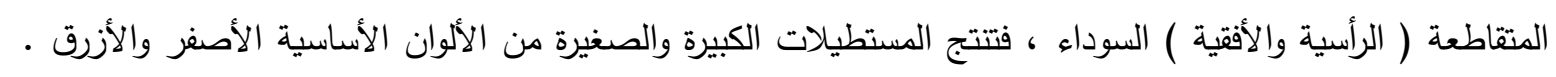

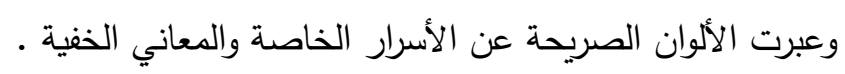
التحليل الفني : نجد التأثير الصارم لمبدأ النظام فقد اتخذ الفنان الرسم التجريدي من مستوي الزخرفة ـ ـ واستخدم الفنان الألوان في كامل شدتها ونضارتها ليثري العمل الفني بالمشاعر المتوهجة والطابع الانفعالي وبالحيوية .

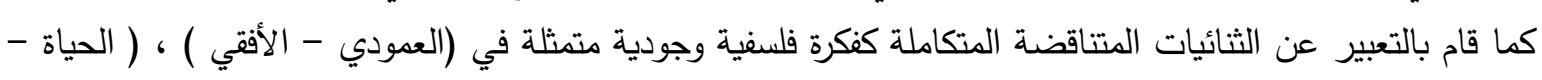
الموت ) ، ( المادي - الروحي ) حيث الالتقاء بين الأفقي والرأسي أو بين الضوء والظلام ، وتثعرك القوة الكامنة في 
الثكل المتتاقض ببهجة وروعة جمالية ـ ويسمح التوازن السكوني لتقوية الاحساس بالحركة الايقاعية كمعادل لحركة الوجود . وقام الفنان بتثكيل معني الصفاء بتكوينات تمثل العلاقة بين الأرض والسماء وتعبر عن الحياة دون الخوض في المظاهر الطبيعية ـ كما طور فكرة ( العمودي _ الأفقي ) التي تتاولتها التكعيبية التحليلية وتتبعها لتصل إلي نهايتها لتعني المنطقية والي التجريد الذي يتحول بالخطوط المنحنية إلي العلاقات العمودية الأفقية .

ثالثا : غياب ذات الفنان :

من غير المدكن قراءة الفن الإسلامي عبر فنانين ، أي لا تحضر أسماء الفنانين ، وأن حضرت كمعان أو كعوالم فنية

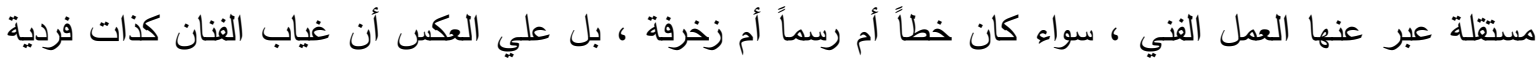
تحمل صفات خاصة بها ، مبدأ من فلسفة هذا الفن ، وخصوصية من خصوصياته الجوهرية. اذن كيف يمكن أن

$$
\text { يحضر الفن ويغيب الفنان ؟ بمله }
$$

ولتفسير ذللك نتتاول الجانب العملي أولاً ، فعلي سبيل المثال " المنمنمات " ـ المنمنمة وبالرغم من صغر حجمها إلا أنها لم تكن نتاج فنان واحد ، أو جهد شخص واحد ـ بل هي نتاج جماعي فهي أولاً تصور يطرحه ويقدمه المعلم ، وثانياً تصميم أولي أو ترجمة للتصور يقوم به المصمم أو المنفذ ، فيترجمه إلي خطوط وأشكال وعلاقات ، ثم يجئ دور الملون الذي يحضر ألوانه من مسحوق أحجار الياقوت والزمرد وسائر الأحجار الكريمة. ثم يجئ المذهب والهيه والذي عليه

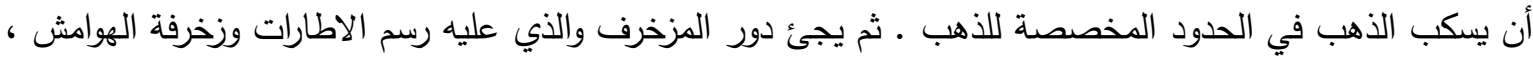
ثم يجئ دور الخطاط إذا كان ثمة كتابة في المنمنمة ـ ونجد ذلك كما في (شكل ه) الوصف : تبدو منمنمة تحتوي علي رسوم وكتابات وزخارف في الأعلى ، كما يوجد مجموعة من الأثخاص يمتطون الخيول وفي خلفية المنمنمة زخارف

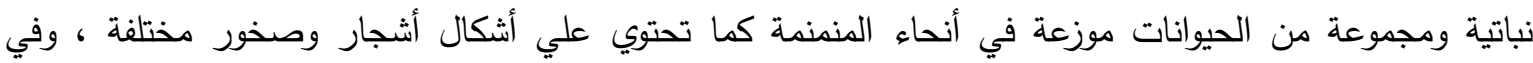
الأسفل نقوش كتابات عربية زاهية علي خلفية ذهبية - من جناح المنمنمات في متحف توتب كابي - استانبول - تركيا

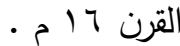
التحليل الفنيـٍ الفنان لا يحاكي الأصول أو النماذج الطبيعية ، بل يركز علي الخواص والتتاسق الجمالي والتلوين

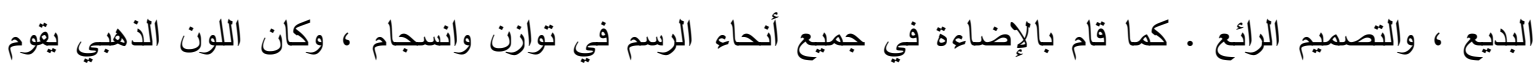

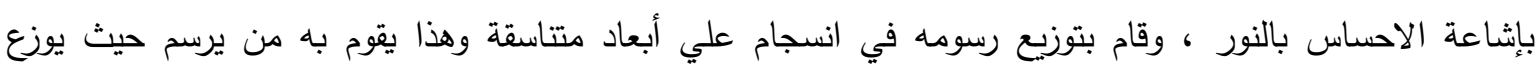

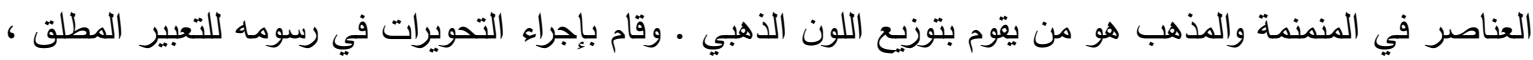

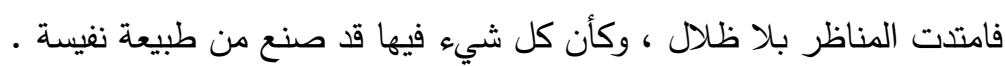
واللوحة غنية بألوانها وبالتعبيرات العاطفية المختلفة ، وقد نجح في استخدام حركات الأيدي في التعبير عن الحوار .

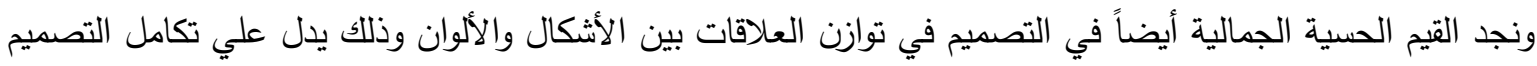

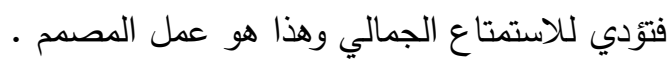

كما نجد التتوع في العناصر الشكلية مما يوحي بالثراء الثكلي حيث نجد الإنسان أو النبات أو الحيوان فنجد نظام

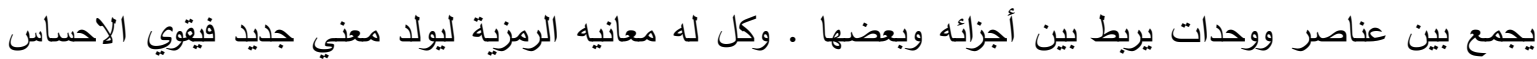
بالبهجة الجمالية ـ وتظهر الألوان مبهجة للعين وتحلق بخيال المشاهد وسط عالم شاعري وجميل ـ وهكذا شمل الفنان في موضوعات أعماله كل جميل ورائع الحس ، وتحقق البهجة بمسحة من وقار • كما نجد التتاقض بين الوضوح والغموض في العالم الممثل ، وبين الوجود المستقل للصور ، وهناك ثنائية في الرسم بين الواقع الظاهر والحقيقة الباطنة مما يعطي الاحساس ببهجة وروعة العمل الفني . 
أي أن هدف الفنان الإسلامي أن يرسم صورة رائعة الحس جميلة ، تجمع بين الرسم والتصميم والتذهيب وفن التتفيذ مما

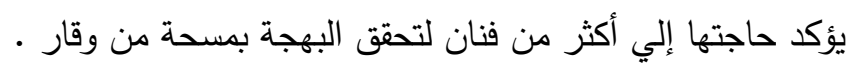

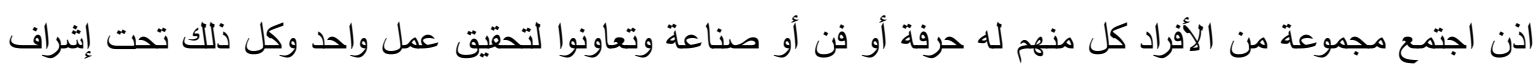

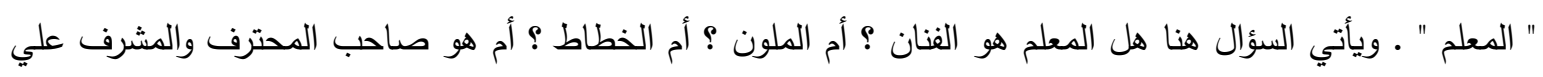
إدارته ؟

ان الفنان هو الجميع ، وهو أيضاً كل واحد بمفرده من هذا الجمع • وبالتالي الفنان هنا هو " الاتقان " و " التقنية " ،

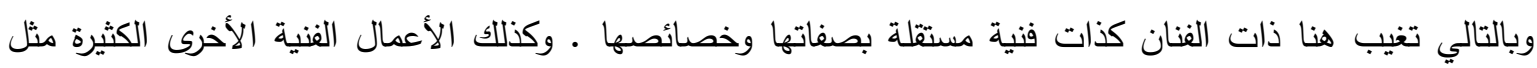

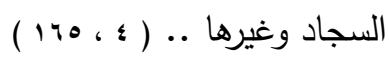
أما في الفن الحديث فقد تثكلت صورة الفنان في النصف الثاني من القرن الثامن عشر علي أنه " الإنسان العبقري " الذي في استطاعته أن يبدع شيئًا من العدم • والفنان يبدع من خلال حسه الرؤيوي دون الحاجة إلي الفهم ، ويطمح إلي الوصول بالفئن الفن إلي اللامحسوس وإلي الكلي

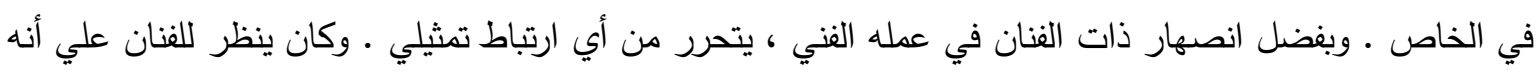

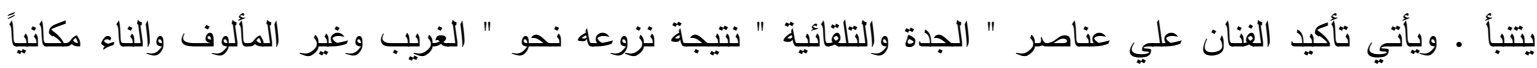

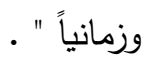

ولقد صورت الرومانسية " الفنان " علي أنه بطل نشأ في عالم خيالي ، وشخص مثالي قوي التأثير ، يهدف إلي غرس

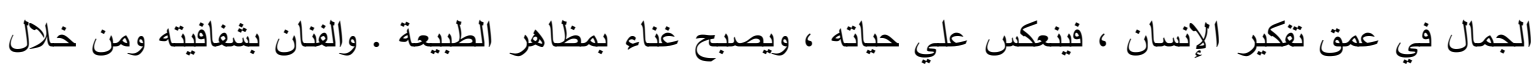

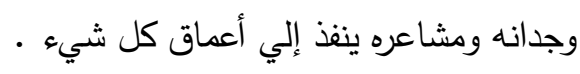
هكذا استخدم الفنان أسلوب التعبير عن الحياة بعمق ، في انسجام معاء مع مشاعره ، وكان مبدأ الفنان أن قوي الجمال

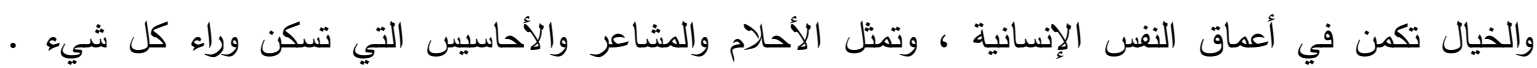

إن الفنان في المجتمعات الحديثة ، يشعر بزهو بذاتيته وتحرره ، وتدور أفكاره حول ذاته وتتحصر تجربته الفنية في

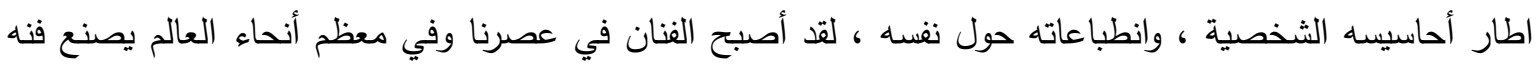
بنفسه وذاته دون وصاية عليه بفضل موهبته ـ. وبالتالي هنا كان الفن الحديث هو تعبير عن ذات الفنان وتأكيد

ومقارنة بين الفنان المسلم والفنان الحديث ـ نصل إلي حدود التناقض والاختلاف ـ فالفنان الحديث ذات الفنان هنا

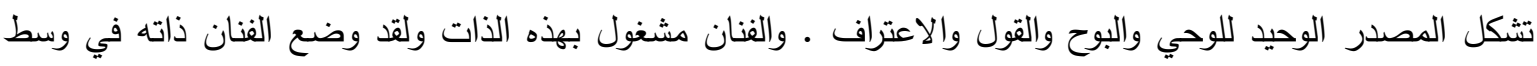
الدائرة كنقطة مركز ، وراح يدور حولها كما يدور محيط الدائرة حول نقطة المركز . فذات الفنان هي أيضاً مركز الكون لهن

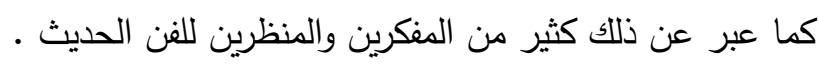
ففي كتاب عصر السريالية يتحدث " والاس فادلي " عن الفردية والذاتية ككلمات يمكن عبرها فهم الفن والأدب الحديثين

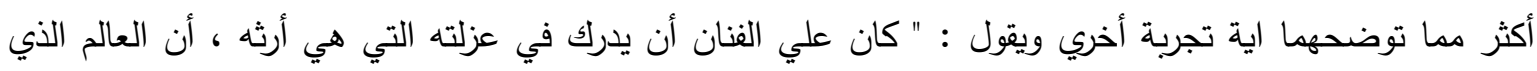

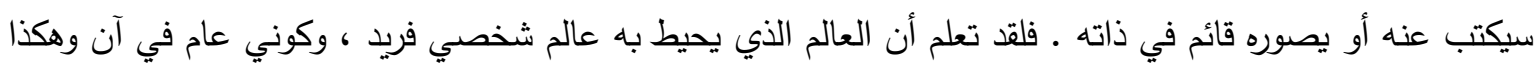
صار هم الفنان الحديث وشاغله الأول أن يجد في ذاته ما هو أصل وما يمكن في الوقت نفسه أن ينقل إلي لغة كونية

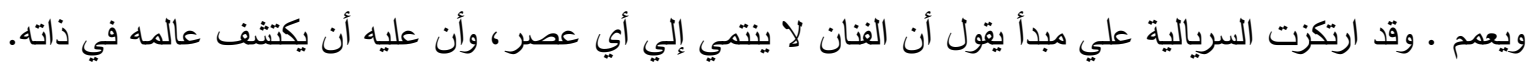

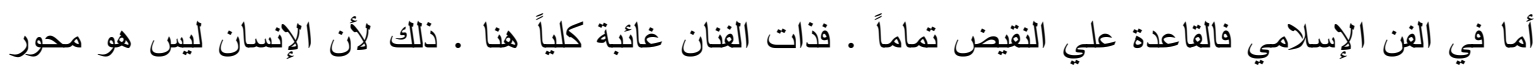
الكون ، بل الله هو محور الكون ، وهو نقطة المركز الذي يدور حولها العالم بأسره ، بما فيه الإنسان أو الفنان . 
لنتأمل نص الرسالة كتبها خطاط معلم إلي طالب يقول : " إذا أردت أن تحظ ، فلتحرر نفسك أولاً من أفكارك تماماً ، ولتدع نفسك علي سجيتها ، وطبيعتك علي حريتها .. عليك قبل أن تبدأ ، أن تجلس في هدوء تام ، حتي يتهيأ للك السلام ، وتتهاوي عنك الظنون والمتاعب ، وعليك أن تميل إلي الصمت ، وألا تتتفس إلا في حدود الضرورة ، ولتتريث فأنت في حضرة وقورة . عندئذ توافيك القدرة " .

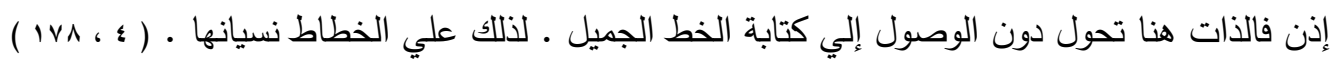

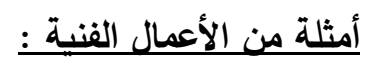

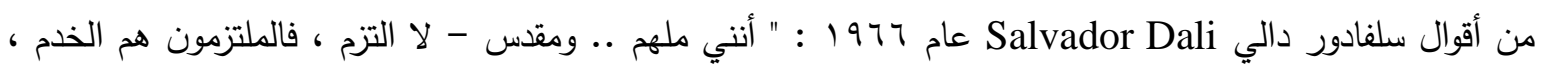
بل فوضوي.. فأنا أعظم فناني عصري .. استعنت بالصور الفوتوغرافية الملونة ، وربطت بين تقنيتها وبين إبداعي،

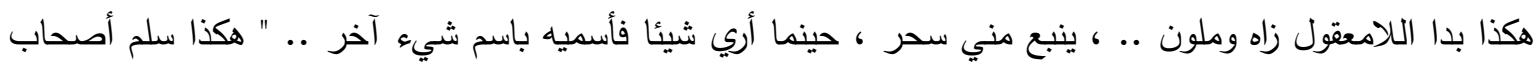

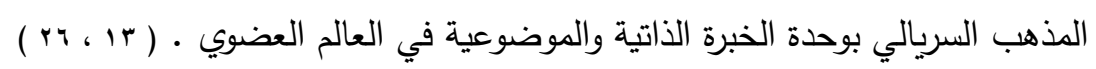

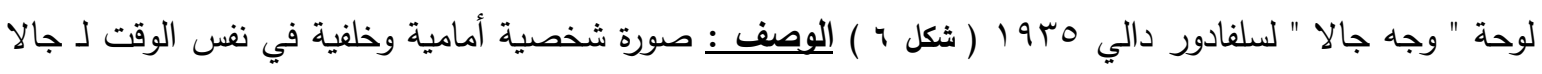
جالسة في حجرة وضع المواجهة والظهر معاً، ترتدي ملابس تشبه زي الفلاحين الممثلين في اللوحة المعلقة علي الجدار الخلفي • وتبدو السيدة في وضع المواجهة تجلس علي كرسي بعجل ، أما التي في وضع الظهر تجلس علي تلي

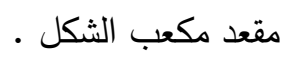
التحليل الفني ؛ تظهر لنا القيم الحسية الجمالية في التصميم من حيث التماسك في توازن العلاقات بين الأشكال

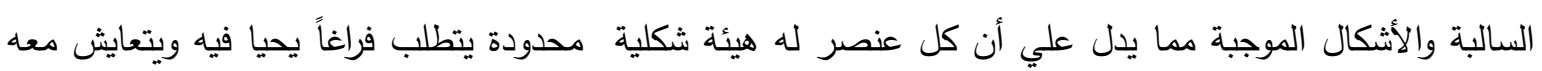

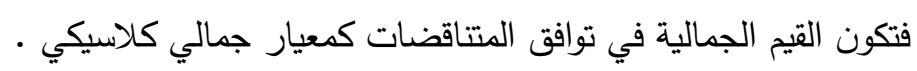

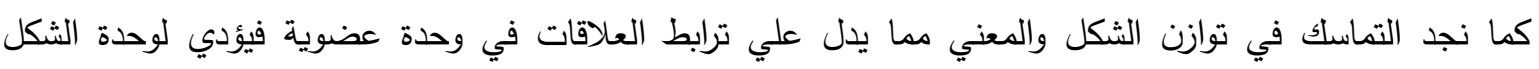

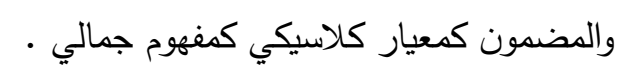
كما يتميز التصميم بصيغة شكلية سائدة رغم تضمنه لأفكار عديدة مما يدل علي الوحدة والثراء والخصوبة وبالتالي

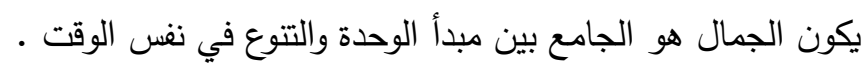
كما نجد القيم الحسية الجمالية في التصميم من حيث التضاد في التتاقض بين الوضوح والغموض مما يشعرك بالقوة

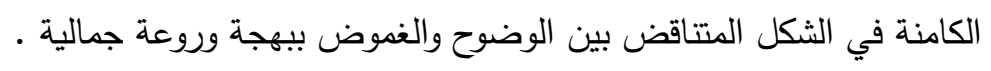

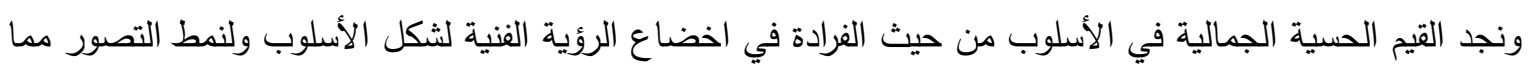
يدل علي إعادة الخلق وفق طريقة الفنان ومنها يكون هدف الفن هو خلق وقائع جمالية جديدة بأبعادها التعبيرية والوجدانية . كما نجد الأبعاد الرمزية والتعبيرية في الخيال حيث يرصد الفنان الطبيعة ممتزجة بانفعالاته وحالته المزاجية مما يعبر

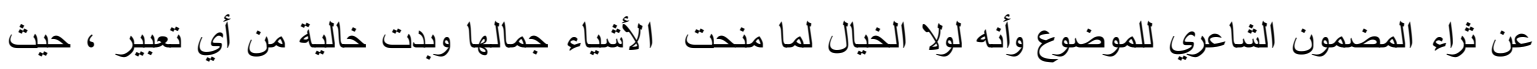

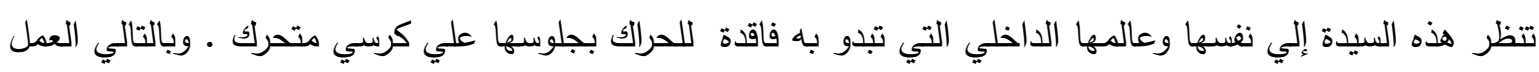

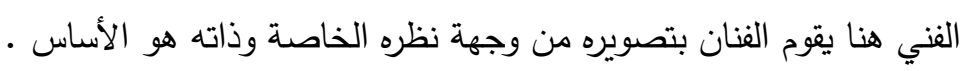

رابعا : الوظائفية :

لقد حمل الفن دائهاً وعلي مر العصور وظيفة أثارت حتي الآن جدلاً فنياً واسعاً ـ والفنون الإسلامية أدت الي الوظائفية

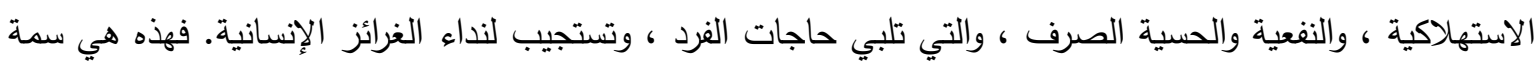
أو خصوصية هذا الفن الإسلامي وهي تميزه وتقرده بين الفنون الأخرى التي عرفتها الحضارات السابقة أو اللاحقة . 
لقد كانت الفنون رسائل خفية موجهة من السلطة الحاكمة محددة وواضحة توضح كفاح وانتصارات الثعوب ، ولازال

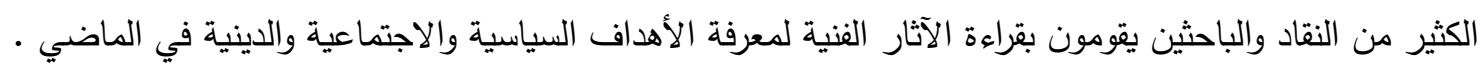

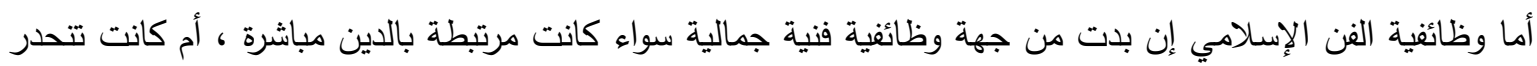

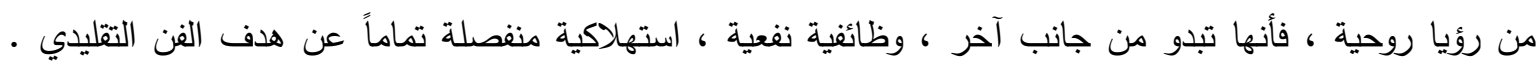

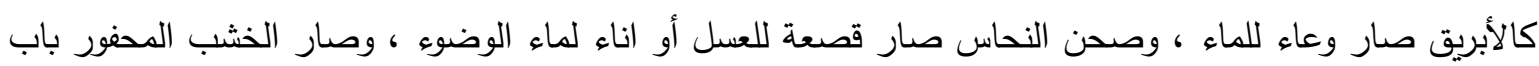
ونافذة وكرسي وسرير وصندوق وغيره ..

لقد توظف الفن في الحياة اليومية ، وفي الحياة الحسية كوسائل وأدوات ، وآلات لبت الحاجات في الحياة اليومية .

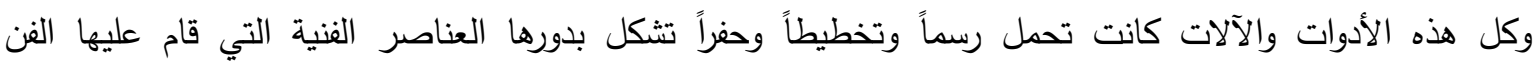

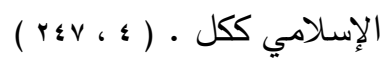
لقد ذكر " جلال الدين الرومي " أن الصورة الظاهرة إنما رسمت لكي تدرك الصورة الباطنة ، والصورة الأخيرة تشكلت

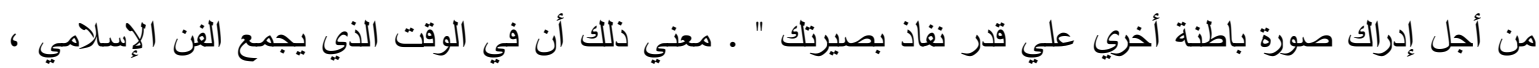

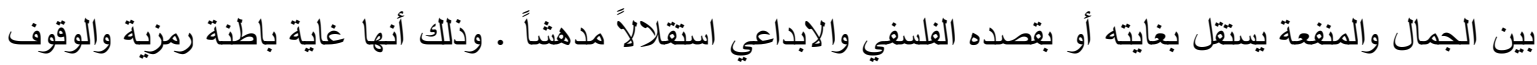

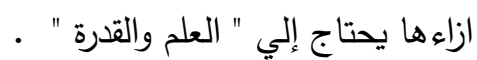
اذن هي وظائفية تلتزم منهج الثنائية المتعددة المتوالدة من نفسها ـ فهي تتحلي في قطبين .. قطب يشهر علي الغيب عن طريق الدين والروحانية ، وقطب يشهد علي فلسفة جمالية شاملة .

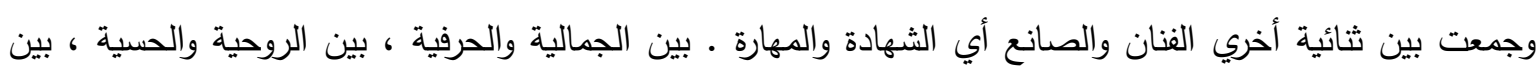

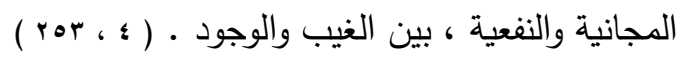
كما نري في ( شكل v ) الوصف : علبة من البرونز المكفت بالفضة ، مزخرف بأشكال حيوانية ونباتية ـ ومخطط

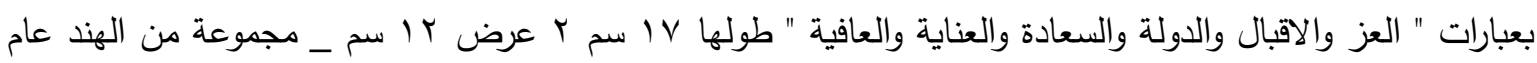

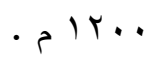

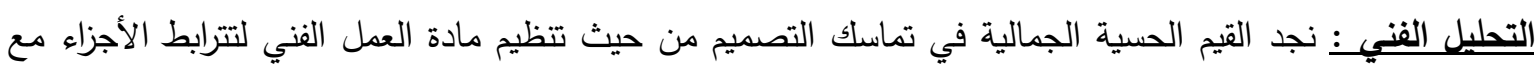
بعضها البعض ومع الكل حيث أنه وضع الكثير من الزخارف النباتية والحيوانية ، وجمال الشكل هو حالة من حالات

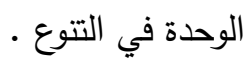
كما نجد التراكب في التصميم حيث التخطيطات متداخلة ومتراكبة في العناصر وبذلك يكون التخطيط معقد والتخطيط

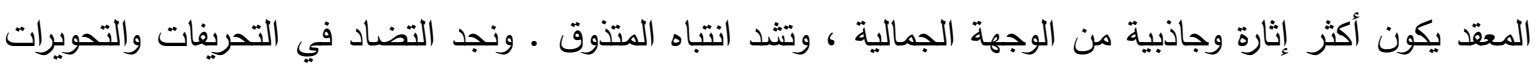

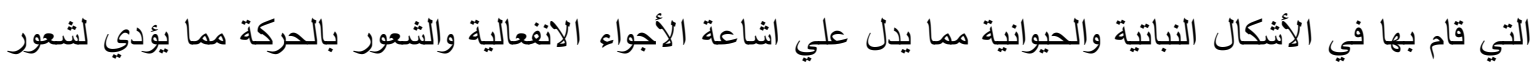

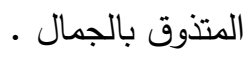

ونجد الفرادة في الأسلوب من حيث التعقيد في التركيب الثكلي والتعقيد في العناصر الرمزية مما يوسع مجال الخبرة الفنية وتعميق مستوي الإدراك الفني لمعني القيمة الجمالية ـ ونجد القيم الوظيفية في ملاءمة العمل الفني لحاجة

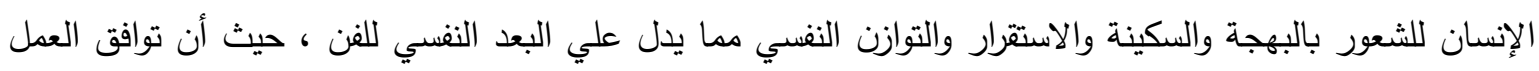

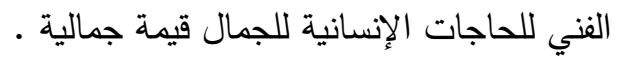
وعند التناقض بين الوظائغية في الفن الإسلامي والفن الحديث فنجد أن الفنون الأوروبية انحصرت بالعمل الفني نفسه ،

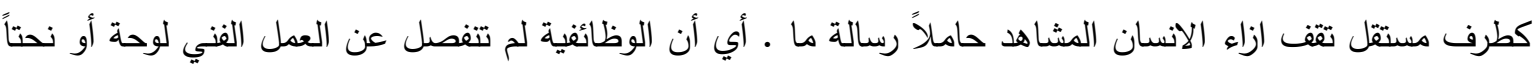

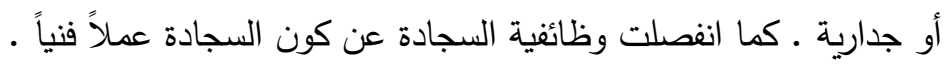


اذن لقد ارتبطت وظائفية الفن الحديث بالمضمون الذي كان يجسده أو يتتاوله الفن ، وبالتالي فإن العمل الفني منذ

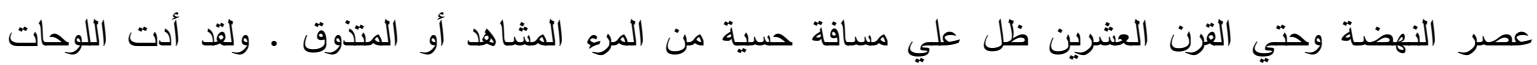
والمنحوتات وظائف عديدة عبر هذه القرون لكنها لم تصل إلي حدود الوظائفية الإسلامية .

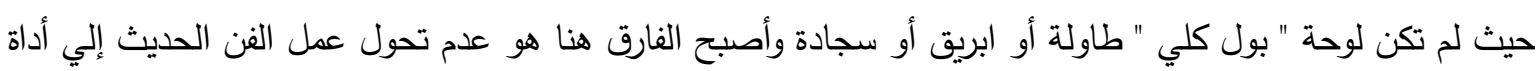

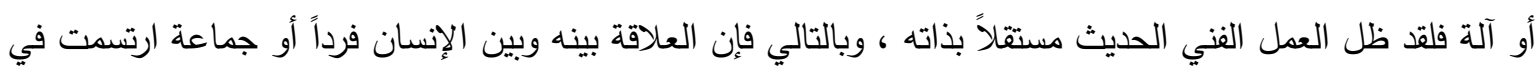

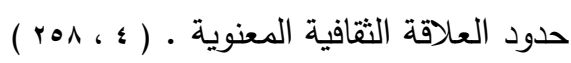

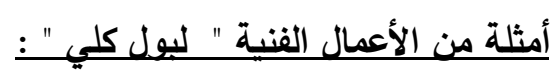

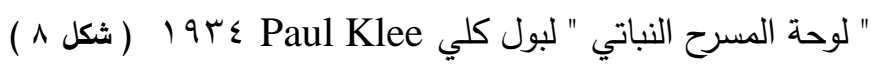
الوصف : مجموعة من الصور مفككة وأعاد تركييها من وحي الخيال وقد تتشابه مع البشر والحيوانات والطيور

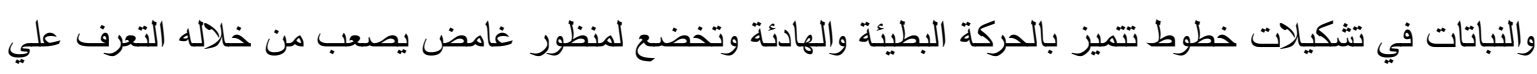
الأثكال ، وتتحرك الخطوط في اتجاهات متعرجة في تصارع أو توتر ـ ويقرب الفنان بين الصور المتناقضة والمركبة

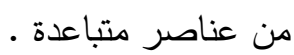
التحليل الفني ذِ نجد القيم الحسية الجمالية في التصميم من حيث التماسك في توازن العلاقات ( الخطوط - الألوان -

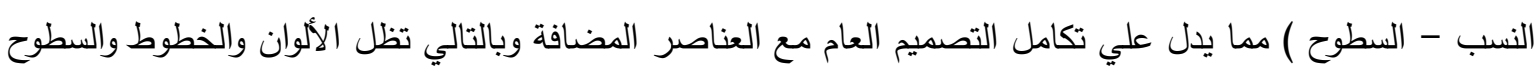
مجرد تأثيرات حسية تتفذ إلي عالم الاستمتاع الجمالي بفضل تميز الرؤية الفنية بالقوة الخيالية .

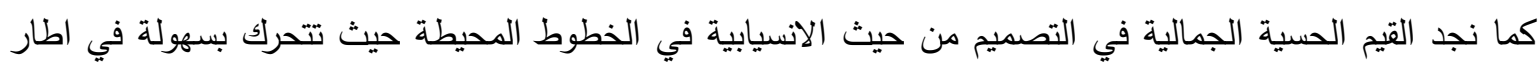

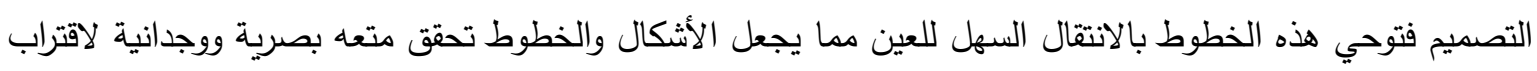
حركتها من حيوية الحياة لإنسيابيتها . كما نجد التتوع في التصميم لوجود عناصر شكلية متتوعة كإنسان أو طيرا أو حيوان أو نبات مما يبعد عنا الإصابة لإنة الإنيات

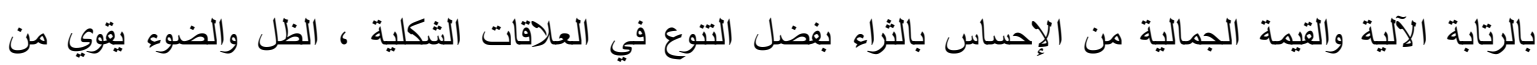
عناصر التشويق والجاذبية الجمالية . كما نجد التضاد في التصميم بالجمع بين الخيالي والعقلي في وجود عناصر حقيقية ولكن بوجهة نظر الفنان الخيالية

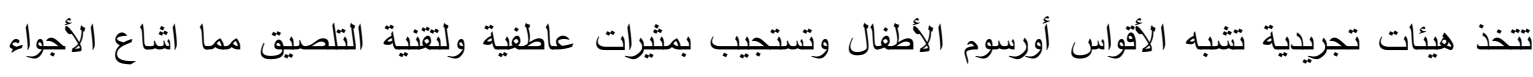

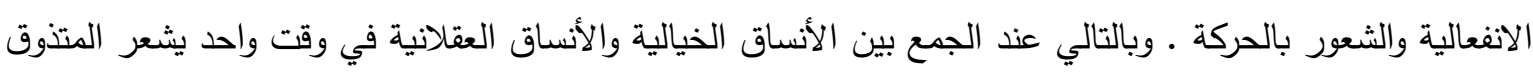

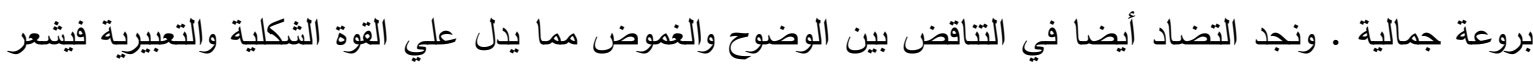

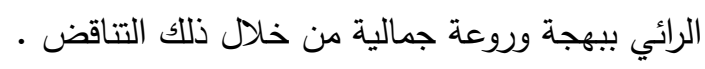
كما نجد الأبعاد الرمزية والتعبيرية في الخطوط الانسيابية حيث استخدم الخطوط المنحنية بكثرة مما يدل علي المرونة

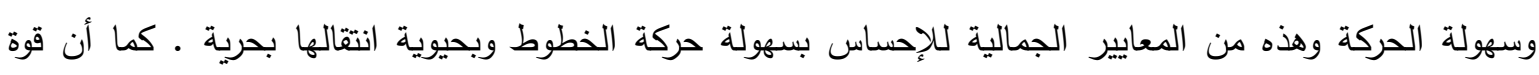

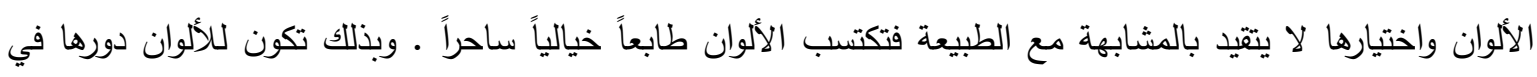
تحقيق القوة الحيوية . ونجد الأبعاد الرمزية في الخيال بإبراز التعبيرات القوية والتأكيد علي الأجواء البدائية والغرائبية في العمل الفني والبناءات

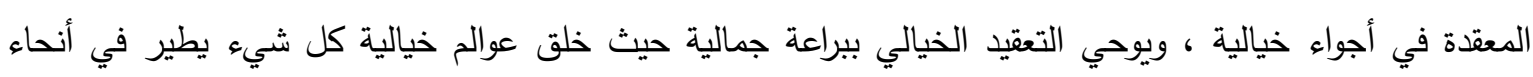

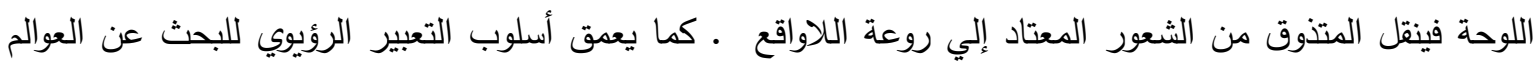


اذن تكون النتيجة ان العلبة هنا بالرغم من كونها مزخرفة بأثكال من الحيوانات والنباتات والكتابات إلا أنها تئدي

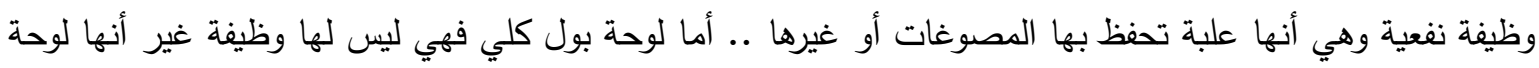

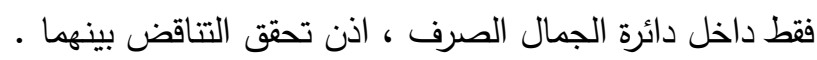
ولنرجع إلي بعض المواقف النظرية التي تتاولت وظيفة أو غاية الفن من وجهة نظر الغرب ونذكر رأي " هيجل" في كتابه " المدخل في علم الجمال " قائلاً : " حتي يكون في مقدورنا أن نصدر حكما علي الجمال يتوجب علينا بقدر

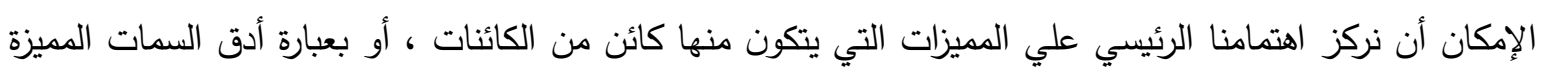

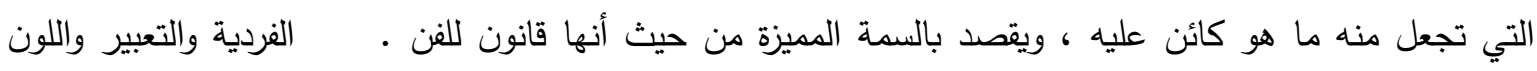

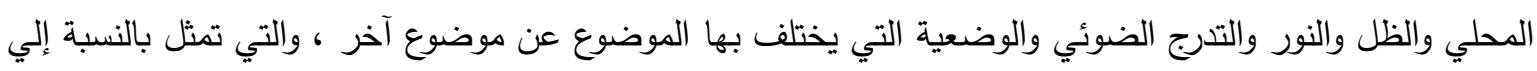
كل موضوع ما يجب أن يكونه " . وعن طريق هذا التعريف نستطيع القول أنه من الصعب جداً قراءة هذه الجماليات

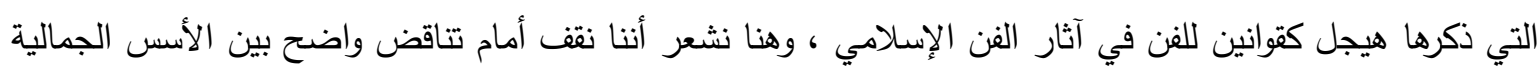

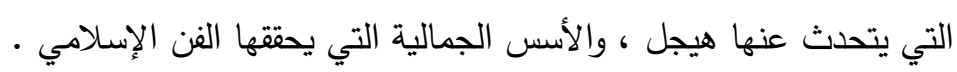

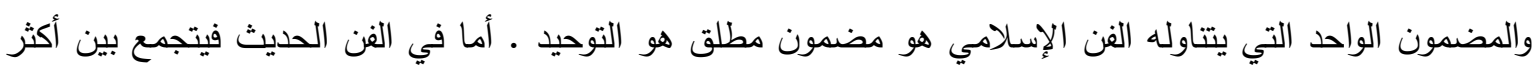

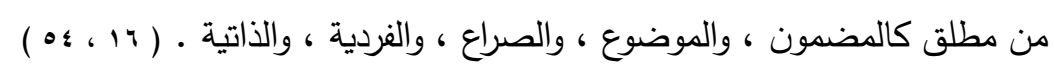

\section{خامسا : محاكاة الواقع الطبيعي :}

عند تأملنا لآثار الفن الإسلامي نلاحظ أن الطبيعة شجراً كانت أم طيراً وسماء ونجوماً وجماداً ، تكاد تكون هي

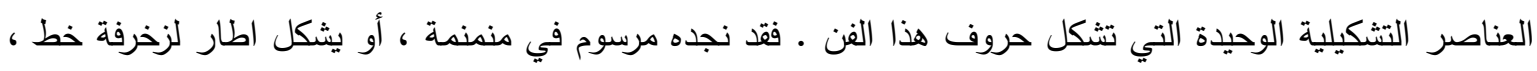
أو منقوش في عمارة ، أو محفور في معدن وغيرها..

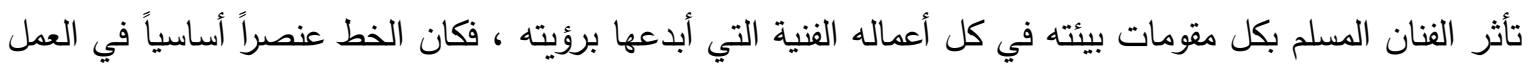

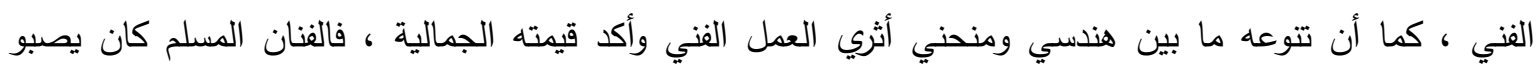
للكثف عن العناصر والمخلوقات ، وحتي يصل لتحوير وتجريد عناصر الطبيعة استطاع أن يحلل عناصرها ثم يعيد

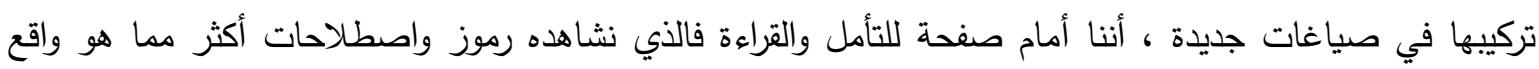

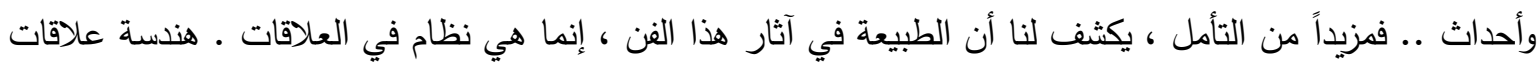

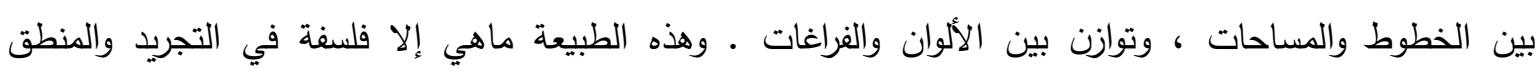

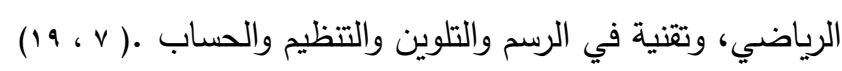

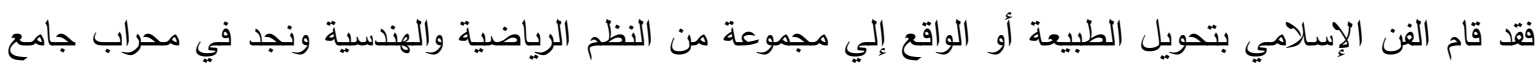
القيروان المصنوع من الخزف ( شكل 9 ) الوصف : نلاحظ الزخارف المتتوعة ، والتي تقوم جميعها علي استلهام الطبيعة ، وبخاصة الأوراق والزهور ـ ذلك بطريقة الاستلهام بحيث لا يتحول الرسم إلي محاكاة للطبيعة. التحليل الفني ذِ نجد القيم الحسية الجمالية في تماسك التصميم من حيث تكرار النموذج في أوضاع مختلفة في الاطار

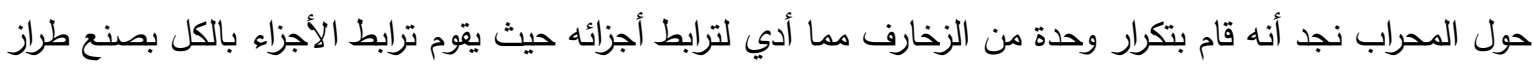

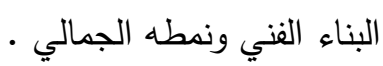
ونجد التراكب في التصميم حيث التخطيطات المتداخلة والمتراكبة مثل تشكيلات التوريق النباتية فيكون التخطيط معقد وبالتالي يكون أكثر جاذبية واثارة وتثد انتباه المتذوق ـ والخطوط تتميز بالانسيابية حيث تتحرك بسهولة في اطار التصميم وهي توحي بالانتقال السهل للعين فتحقق متعة بصرية ووجدانية بفضل اقتراب حركتها من حيوية الحياة 
وقام بالتحريفات في الأشكال بعيد عن الواقع الطبيعي في مقابل المتناسب مما يشعر المتذوق بروعة جمالية ـ ونجد

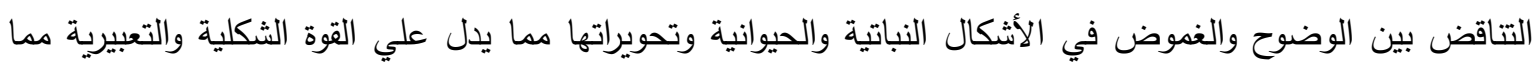
يؤدي للشعور بالبهجة وروعة جمالية . كما قام الفنان برصد الطبيعة ممتزجة بانفعالاته وحالته بحيث لا يتحول الرسم إلي محاكاة مما يعبر عن ثراء المضمون

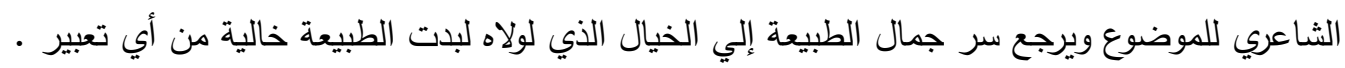

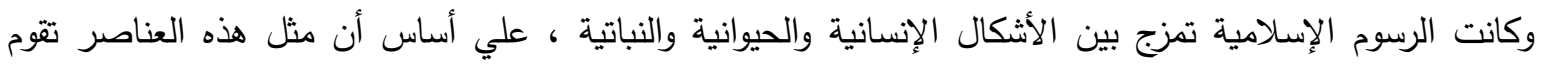
بأدوار متساوية في خلق العمل الفني • وتوصل الفنان إلي تحويرها وتبسيطها ، من أجل أن تحقق الأهداف الجمالية .

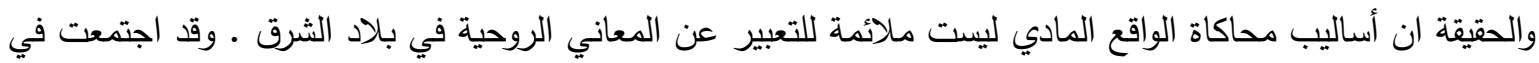

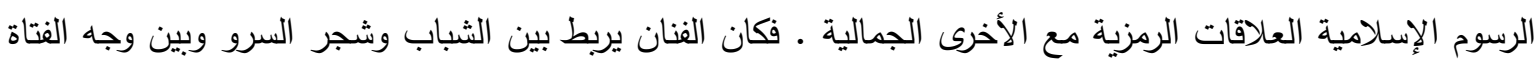
والقرر • وقد استطاع الفنان المسلم أن ينفذ برسومه إلي عالم الوجدان مستخدماً في ذلك كل عناصر التكوين الترين والتشكيل. أما في الفن الحديث فعلي الرغم من الدعوة إلي الخروج إلي الطبيعة إلا أنه سرعان ما تجاوز الطبيعة كموضوع رئيسي،

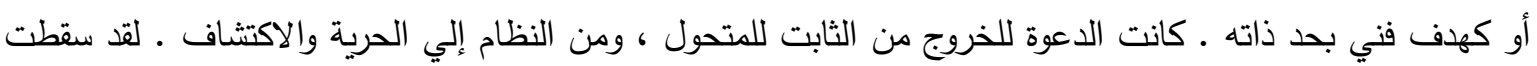

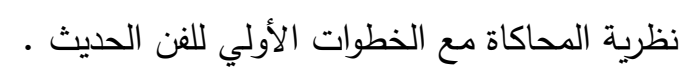
وكان الهدف هو الوصول إلي الباطن وغير المرئي في الفنان نفسه ، والوصول إلي أسراره ـ إن الأمر كان حباً

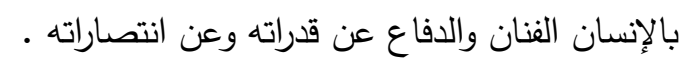

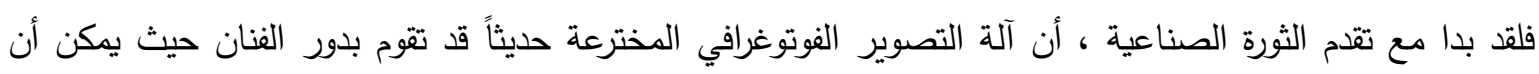

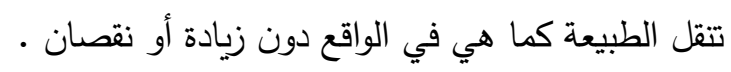

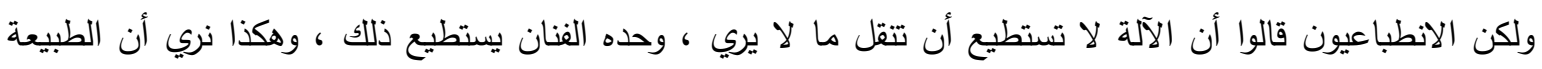

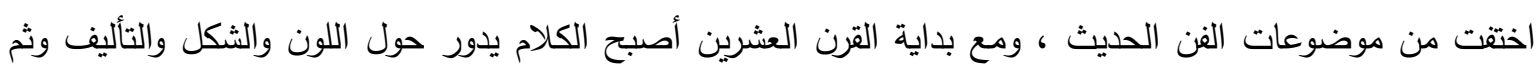

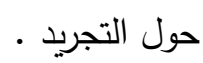
وقد قال سيزان : أن الطبيعة يمكن تحويلها في شكل الأسطوانة والكرة والمخروط ومع تجارب كاندنسكي بدأت الطبيعة تختزل وتتلاشي نهائياً.. إن المنظر الذي يجب رسمه ، هو المنظر الذي يرنسم في الذاني الداخل والذي تعرف كيف تنقله

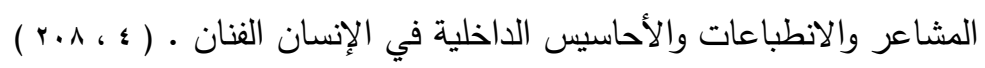
وقد شبه " كاندنسكي " Vasily Kandinsky أعماله في التصوير بالأعمال الموسيقية وكان يستخدم الألوان والأشكال ، والان المجردة وكأنها أنغام ، وفي ذلك المجال تطورت تجاربه إلي أن تكثف لديه إمكانية الاستغناء عن الأشكال الطبيعية .

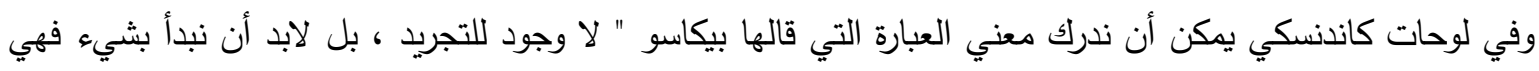

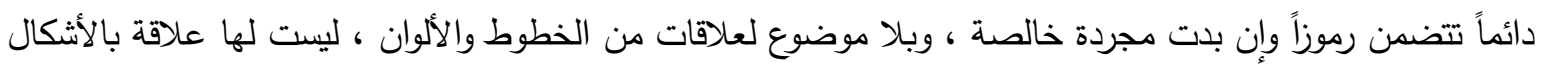
المألوفة التي تراها في الواقع الخارجي ، إنها في الحقيقة رموز مفاهيم ومعاني شمولية ، وتقبل تقسيرات متعددة . وقد قال كاندنسكي أنه يجب أن يصبح الفن مجرداً عن أصله ، ويرتبط بمعني محدد معروف يقصد منه أن للألوان

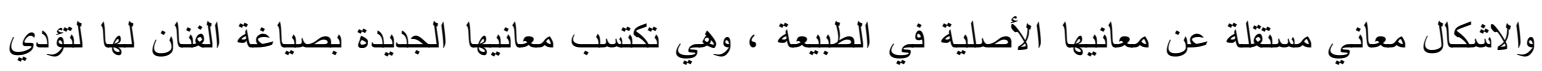

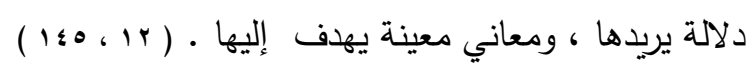

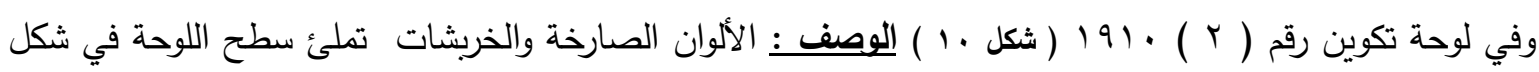

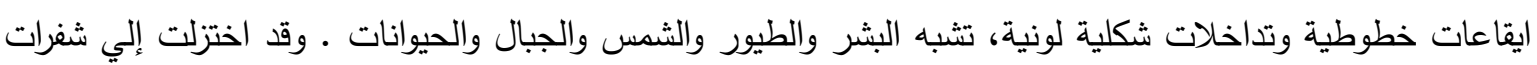
بحيث تتخذ الألوان والخطوط وجودها المستقل ، وتكتسب معاني انسانية ، من صراع بين خير وشر ، رغم أنها تتخطي 
حدود البشر وحدود العقلانية ـ وتبدو اللوحة أنها مجرد خربشات ألوان وخطوط وتبدو أنها تحققت صدفة ، وتعطي جو

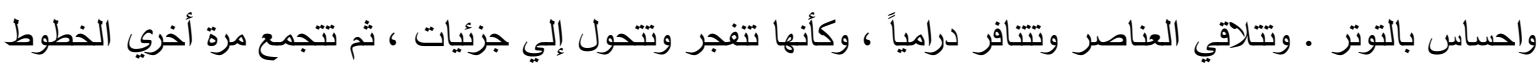

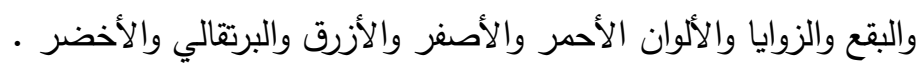
التحليل الفنيـذ نجد القيم الحسية الجمالية في التصميم من حيث التماسك في توازن العلاقات ( الخطوط - الألوان -

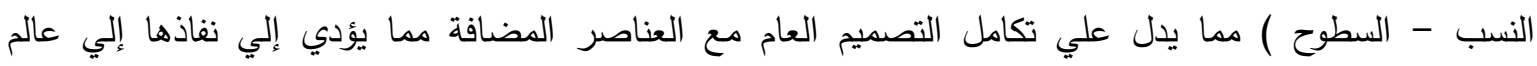
الاستمتاع الجمالي بفضل تميز الرؤية الفنية بالقوة الخيالية .

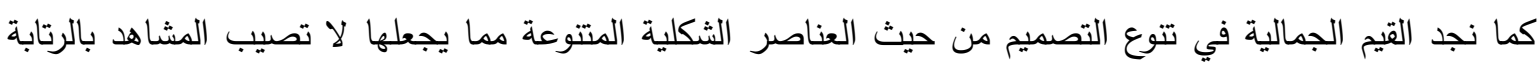
فتقوي الاحساس بالبهجة الجمالية ـ كما قام بالتحريفات في مقابل المتتاسب لإثاعة الأجواء الانفعالية والثعور بالحركة

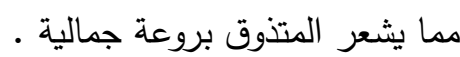
ونجد وضوح الأسلوب في استخدام الألوان بكامل وضوحها وتضاربها لتعبر عن معان رمزية وعن جوانب روحية

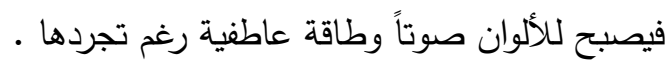
ونجد الفرادة في الأسلوب من حيث اخضاع الرؤية الفنية لشكل نمط التصور مما يؤدي إلي إعادة الخلق وفق طريقة الفنان فيخلق وقائع جمالية جديدة بأبعادها الوجدانية . ونجد الانسيابية في الخطوط حيث استخدم الخطوط المنحنية بكثرة مما يؤدي للمرونة وسهوله الحركة وهي من المثيرات

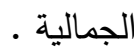
كما نجد التلقائية في الضربات اللونية القوية والعميقة وهي بدون تصنع أو تكلف والتلقائية من الصفات الجمالية. و

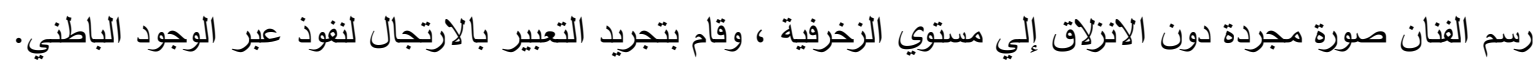

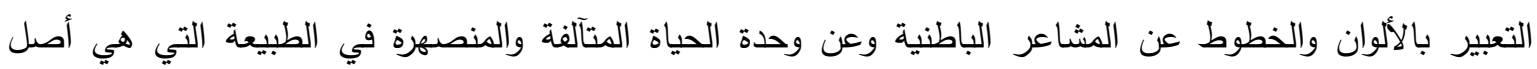
الوجود ـ ونجد وحدة المتتاقضات بين الذكورة والأنوثة ، الطبيعية والعقل ، التوتر والقلق . وفي نهاية البحث وبعد ايضاح التتاقضات بين الفن الإسلامي والفن الحديث والاستشهاد بمجموعة من الأمثلة من الأعمال الفنية والتحليل الفني الجمالي في هذان العصران تؤكد الباحثة فكرة البحث بهذه المقولة : يقول بورخيس : " الكتاب الذي لا يقدم نقيضه .. يعد ناقصاً " . والحقيقة أن الحياة كلها بدون هذه التتاقضات لا حياة

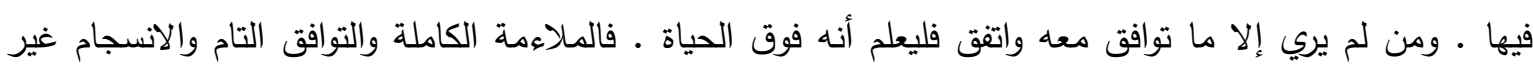

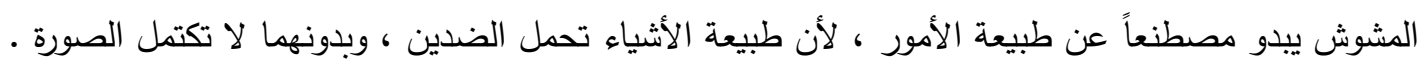

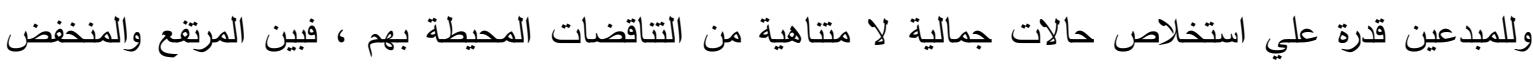
والغامق والفاتح والحلو والمالح والحب والكره ، من بين هذه التتاقضات تولد إبداعات غزت الحضارة الإنسانية . وفي النهاية أتمني من الله العلي القدير أن أكون قد وفقت في هذا البحث وأن يلاقي استحسان الجميع وأن يغفروا

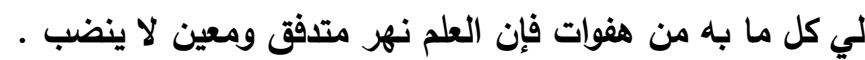


تتاولت هذه الدراسة بالتحليل التناقض بين فن التراث ( الفن الإسلامي ) والفن الحديث وفق نقاط محددة وخرجت بالنتائج التالية : بأن تحرر العمل الفني من الموضوع في الفن الإسلامي سواء كان هذا الموضوع هامشياً أم من الموضوعات الإنسانية

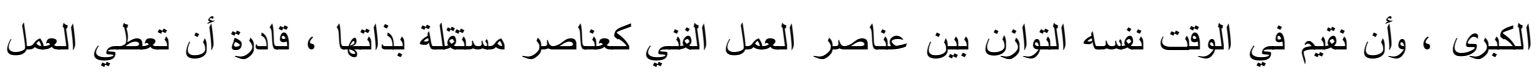

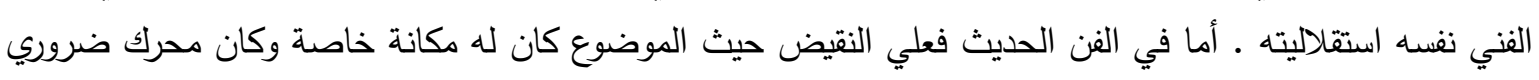
اللفنان

التناقض في التجريد في المصدر حيث ان مصدر التجريد في الفن الإسلامي هو مصدر غير واقعي وغير مرئي حيث يعبر عما هو روحاني وإلهي ، في حين أن مصدر التجريد في الفن الحديث واقعي وحسي ومرئي . اتضح التتاقض في غياب ذات الفنان في الفن الإسلامي كذات فردية تحمل صفات خاصة بهان بها بينما في الفن الحديث

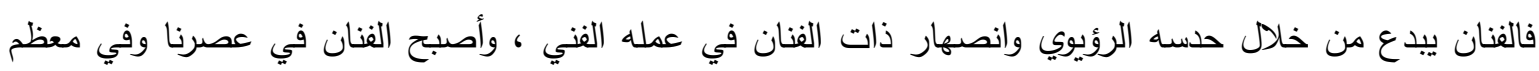

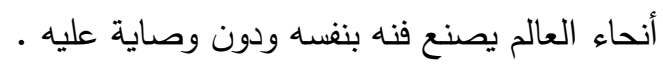

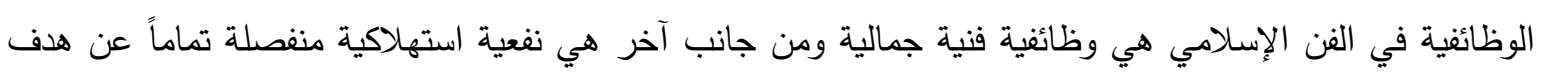

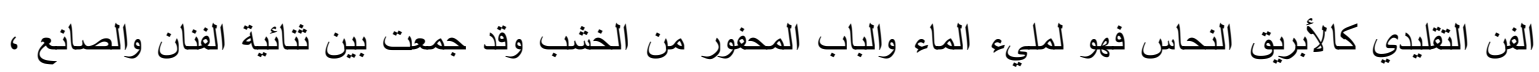

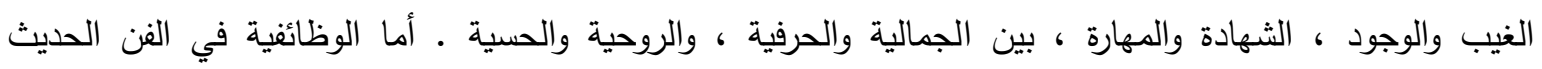

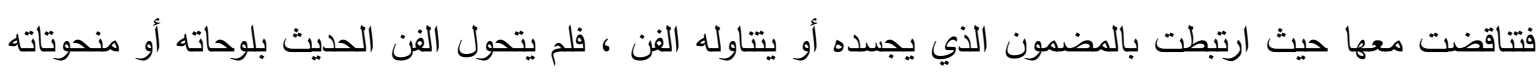

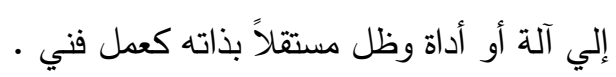
• في الفن الإسلامي تأثر الفنان المسلم بكل مقومات بيئته في كل أعماله الفنية التي أبدعها ولكن برؤيته حيث قام

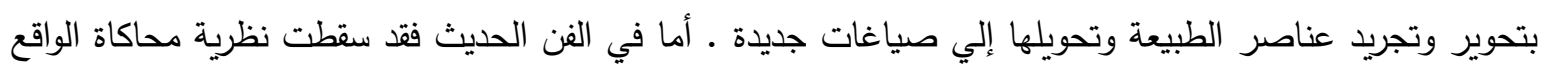

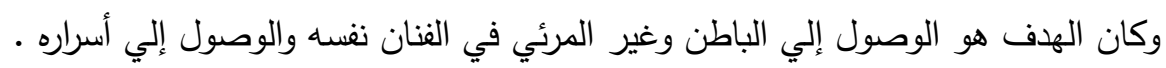
• في النهاية تحقق مبدأ التتاقض بين فن التراث ( الفن الإسلامي ) والفن الحديث من خلاد الفئ القيم الجمالية .

التـوصيـات :

اجراء المزيد من الدراسات حول التتاقض بين الفنون المختلفة لأنه مازال به الكثير لدراسته . تتمية مهارة التفكير الناقد من خلال استخدام التتاقض كمعيار للحكم في مناهج تدريس فنون الحضارات المختلفة . ها التناقض هو وسيلة فعالة لإدراك جماليات فنون الحضارات المختلفة والتأثير علي المتلقي ونشر القيم الفنية والجمالية .

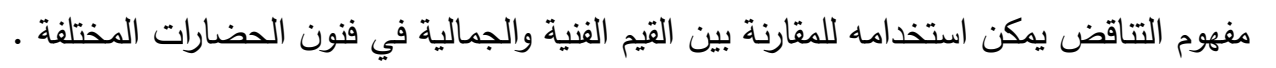

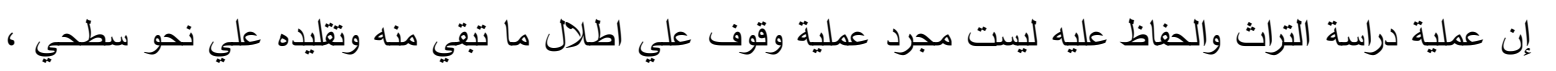

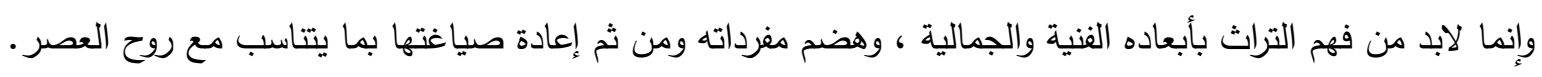
لذللك لابد من توجيه الأبحاث والدراسات المختلفة نحو مثل هذه الدراسات ، لاسيما طلبة الدراسات العليا في الجامعات. 
أولاًً : الموضوع

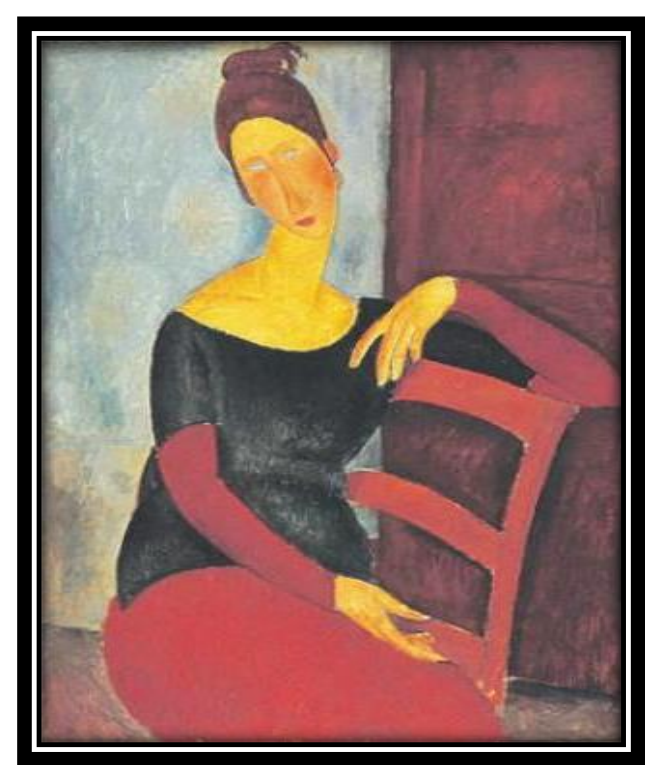

شكل (r) اميدو مودلياني - امرأة -

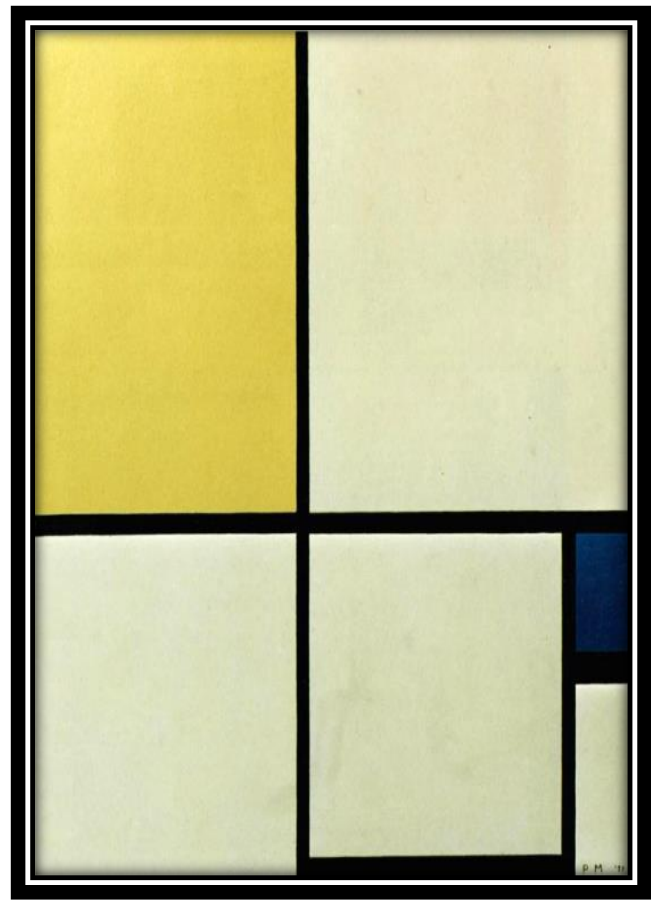

شكل (؛) تكوين بالأصفر والأزرق - بيت موندريان 19 9 १

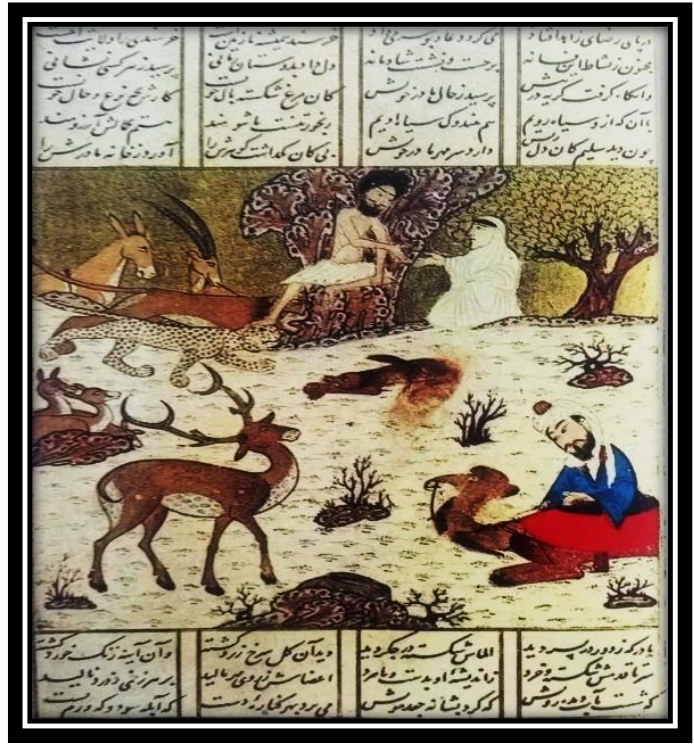

شكل ( ) مجنون ليلي مخطوط الخمسة للشاعر الإيراني

نظامي ، القرن 19 ، مكتبة جون رينلاز ، ألمانيا

ثانباً : التجريد
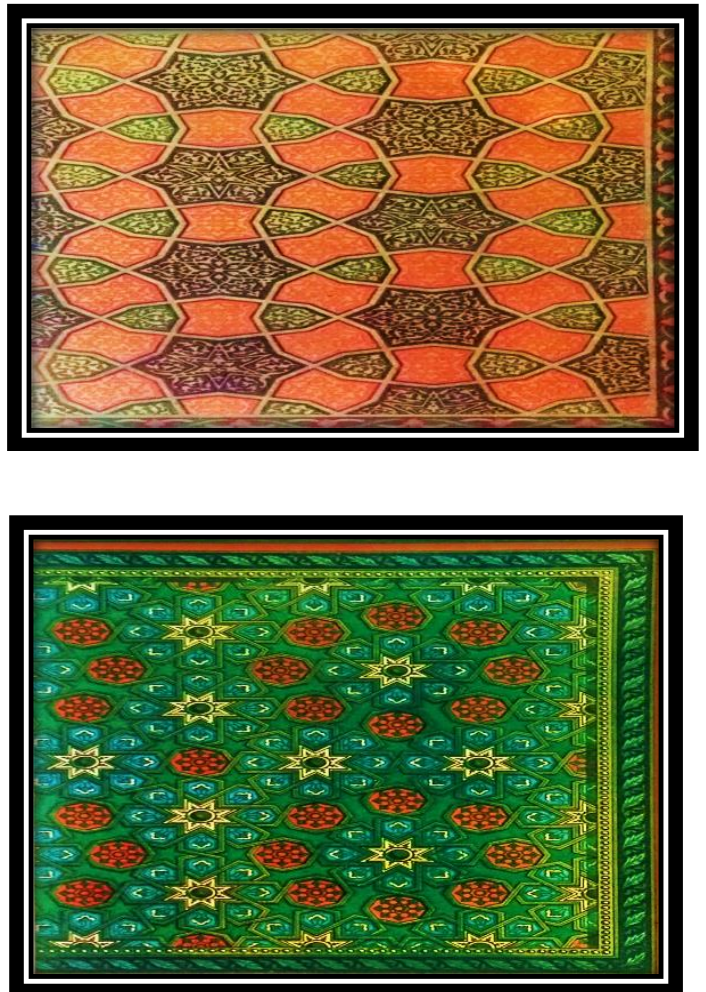

شكل (ץ) جانب من سقف خثبي مؤلف من نجوم سداسية

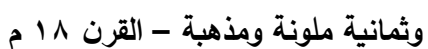


ثالثاً : غياب ذات الفنان

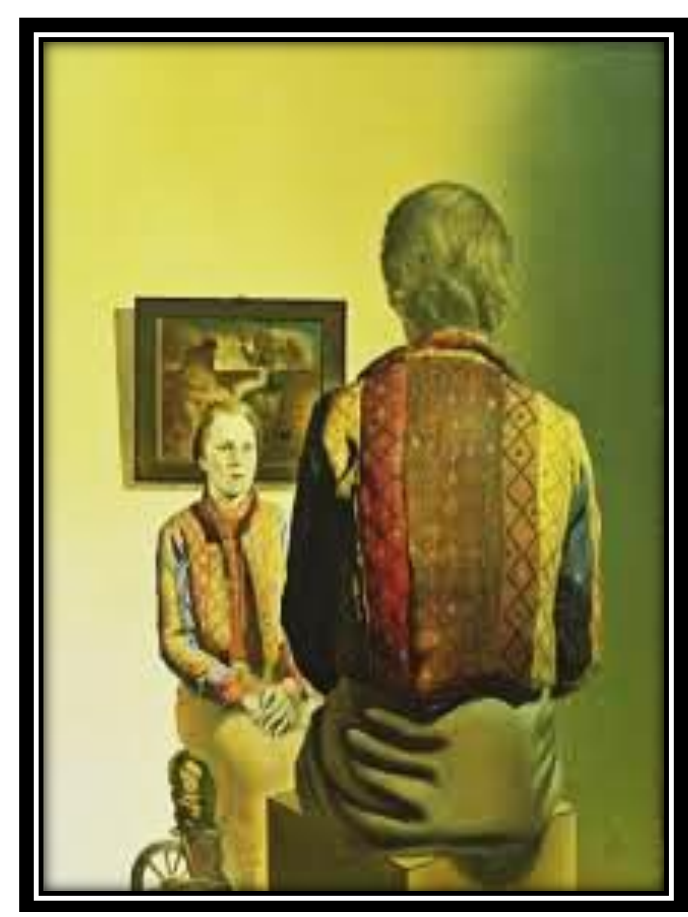

شكل (7) وجه جالا - سلفادور دالي - هب 19

رليعاً : الوظائفية

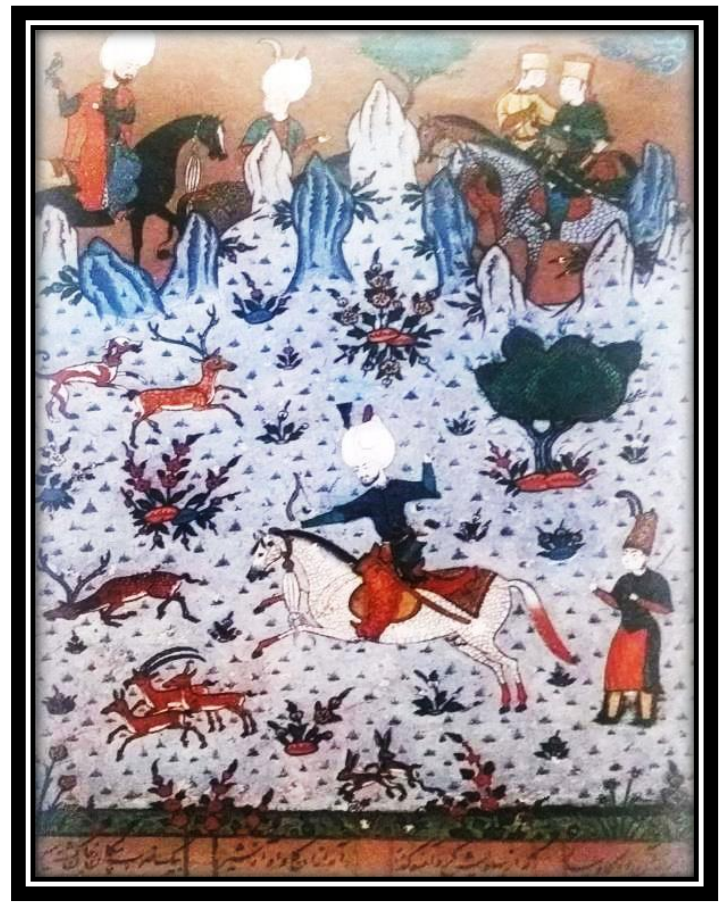

شكل (0) منمنمة تضم فنون الرسم ، الخط ، التذهيب إلي جانب التصميم وفن التنفيذ مما يؤكد حاجتها لأكثر من فنان

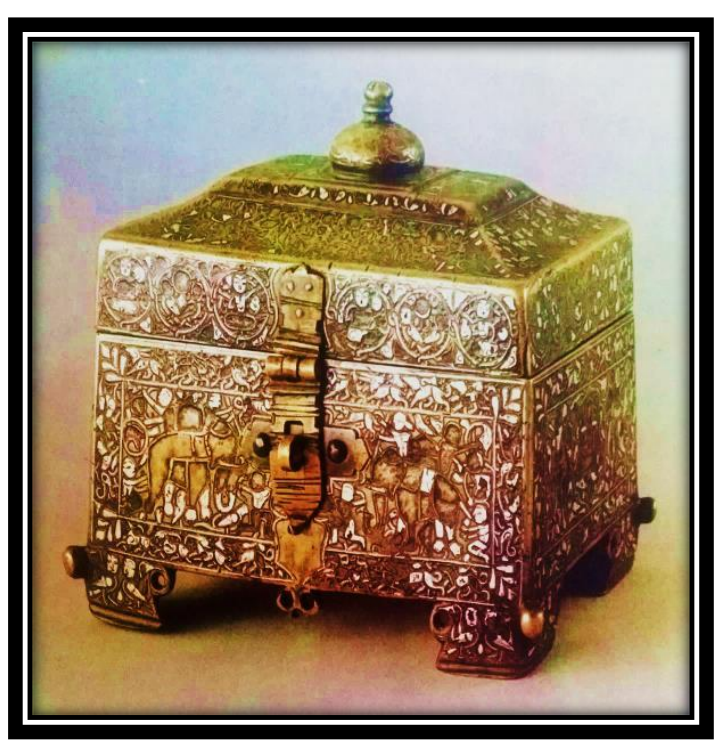

شكل (V) عابة برونز مكفتة بالفضة مزخرف بأثكال حيوانية

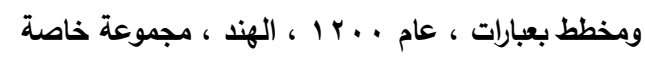


خامساً : محاكاة الواقع الطيعي

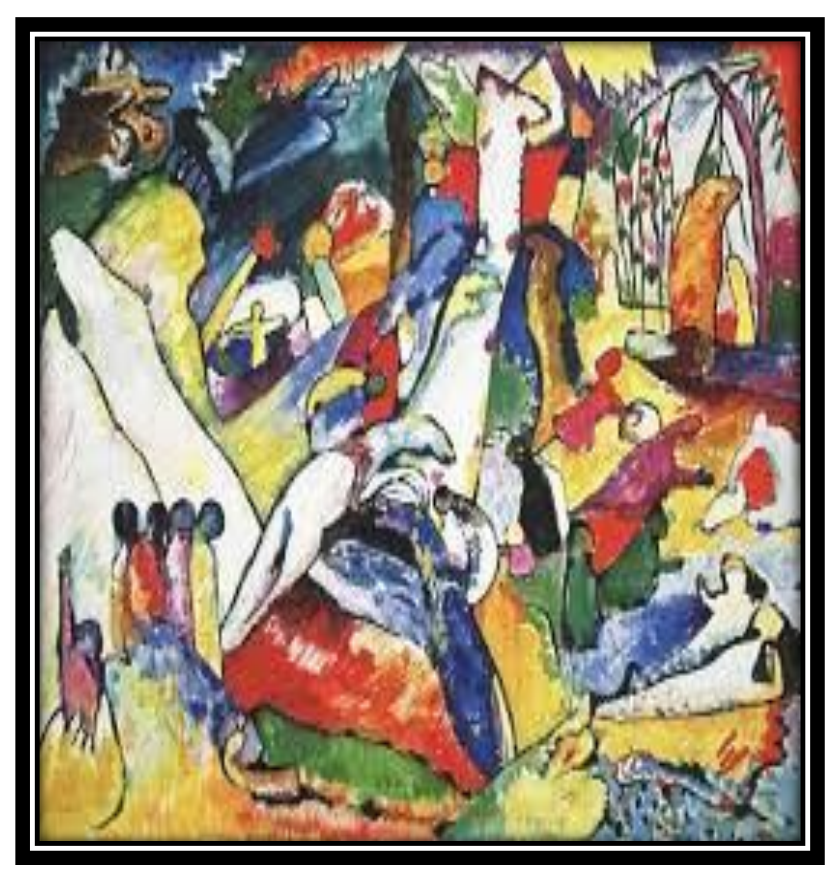

شكل ( • (1) تكوين رقم ץ - كاندنسكي - .

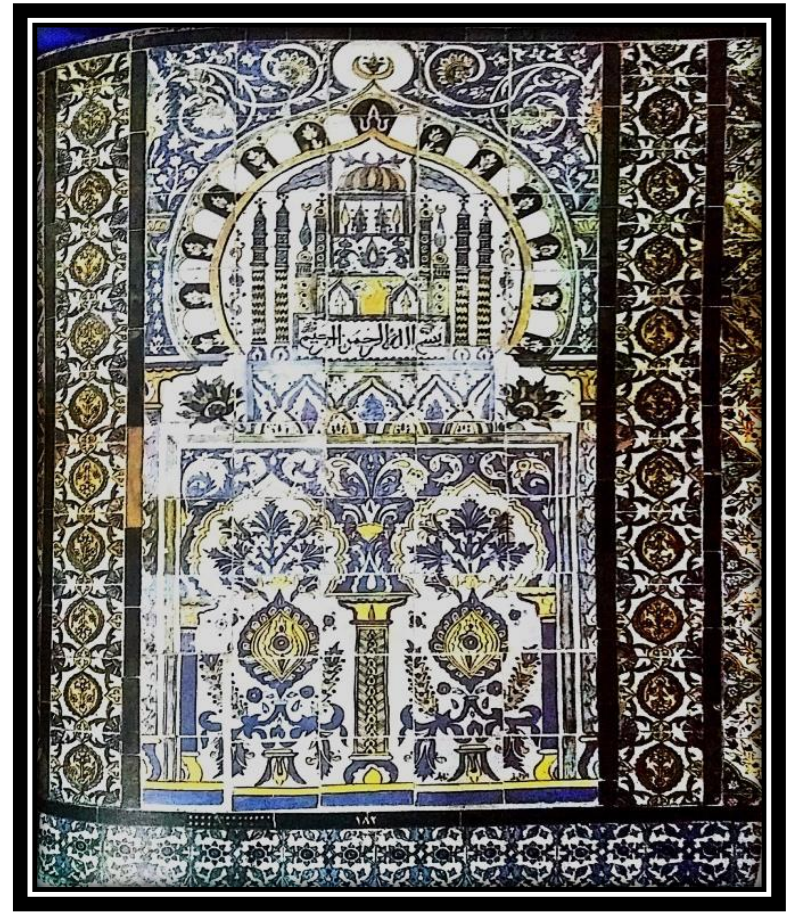

شكل (9) جزء من محراب جامع القيروان خزف ونلاحظ الزخرفة المتنوعة والتي تقوم علي استلهام الطبيعة وخاصة الزهور والأولقاق

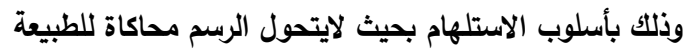




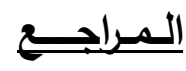

أولا : المراجع العربية : أبية:

الكتب والدوريات والرسيائل العلمية :

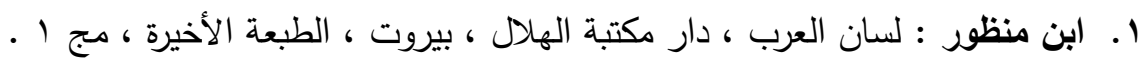
r. احسان شعبان صطوف : الثنائيات المتضادة كقيمة تشكيلية في فن الحفر الأوروبي المعاصر ، رسالة دكتوراه غير منشورة ، قسم الجرافيك ، كلية الفنون الجميلة ، جامعة حلوان ، 0. . ب . r. زكريا ابراهيم : سلسلة عبقريات فلسفة هيجل أو المثالية المطلقة ، دار مصر للطباعة ، مكتبة مصر ،

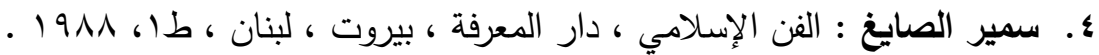

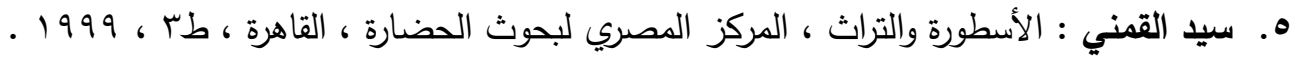
צ. عبد الحميد الكفافي : مقال التراث تعريفه وأشكاله وأنواعه ، المدرسة المصرية الوطنية للحفاظ علي الآثار والتراث

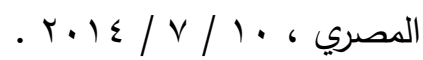

V. عبلة حنفي : مزيد من الحاجة نحو توضيح مفهوم سيكولوجية الفن ، المؤتمر الثاني للجمعية المصرية للدراسات

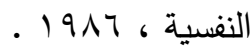

^. عفيف البهنسي : الفن الإسلامي ، دار طلاس للدراسات والترجمة والنشر ، طץ ، 1991 ـ

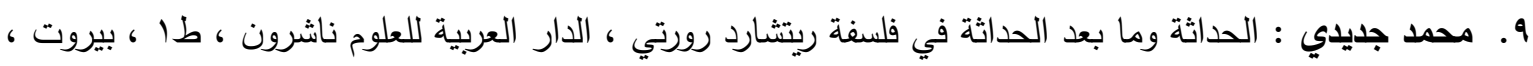

• 1 .محمود البسيوني : أسرار الفن التشكيلي ، عالم الكتب ، طا ، .191 .

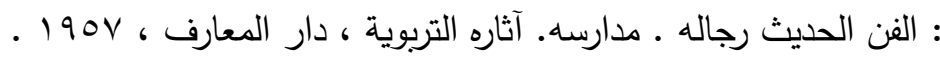
.11

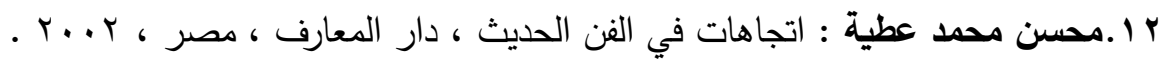

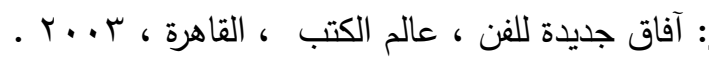
.14

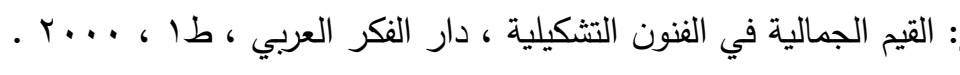
$.1 \leq$

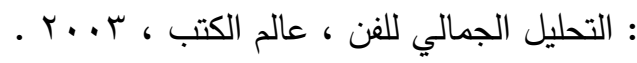
.10 19 ـ هيجل : المدخل إلي علم الجمال ، دار الطليعة للنشر ، بيروت ، طا ، 1911 ، 191 ،

17. http://www.almaany.com/home.php?language-arabic\&word

ثانياً : مواقع الإنترنت :

18. http://www.almaany.com/home.php?language-arabic\&lang-name

19. http://www.marefa.org/

20. https://www.elibrary4arab.com27-2-2013

21. https://www.alnour.com/bible/ot-accusations/346-ot2.html3-3-2011

22. http://www.alazmenah.com/?page=show-det\&category $\mathrm{id}=\mathrm{g} \& \mathrm{id}=54296$

23. http://www.ahewar.org/debat/show.art.asp?aid=1844025/3/2012

24. http://www.ahewar.org/debat/show.art.asp?aid=1307458/11/2012

25. http://www.alfaisalmag.com/?p=76 


\section{ملخص البحث}

" التتاقض " قد تتردد هذه الكلمة لثوان ، لساعات ، وحتي لأيام ، حيث تلتف في دوامة لا بداية لها ولا نهاية .

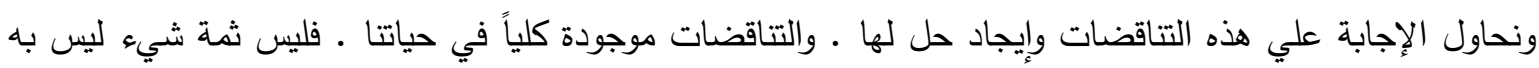

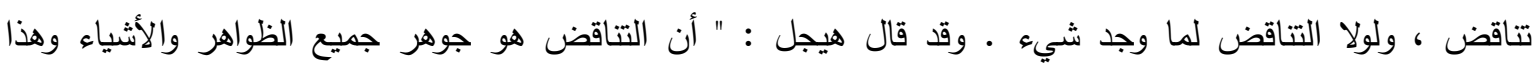
النضال هو منبع كل نمو " .

وتتناقض الأشياء والصفات والمسميات بعضها مع بعض فكل أمر لله فكرته التي بنيت عليها ، كذلك يقوم الكون

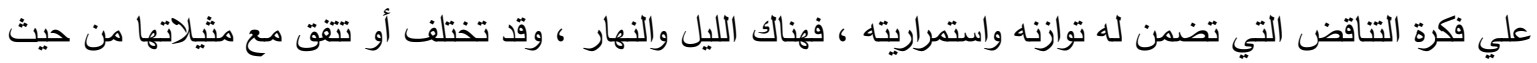

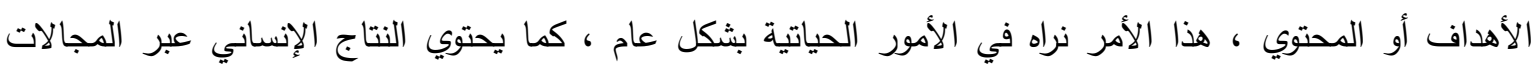
المعرفية والإبداعية علي الكثير من تتاقضات الأمور ، وفي مضمار الفنون تتنوع وتتشعب هذه الفكرة بمدلولها ومعناها الثقافي ، فتتاقض الفنون يختلف باختلاف أنواعها وأدائها وطريقة تتفيذها ومحتواها الفكري أيضاً .

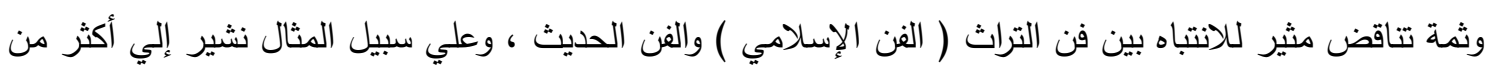

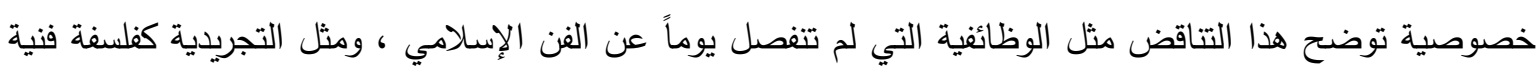

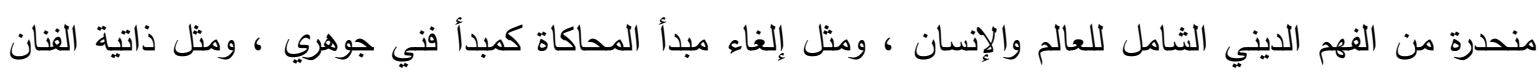

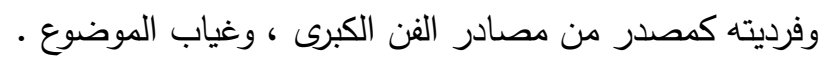

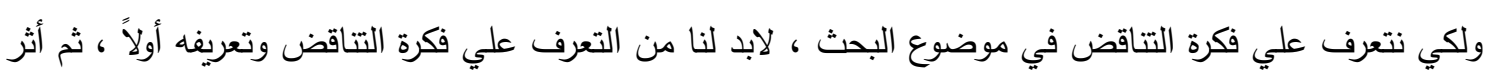

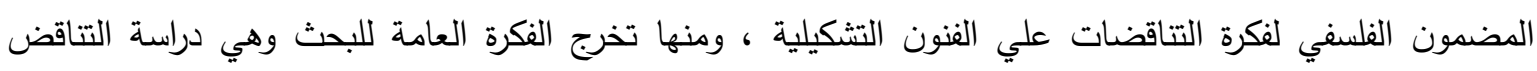
كقيمة جمالية وأثره علي فن التراث والفن الحديث مع إبراز التتاقض من خلال تحليل الأعمال الفنية أيضاً .

\section{Summary}

"Contradiction" This word may hesitate for seconds, for hours, and even for days, where it wraps in a vortex that has no beginning and no end. We try to answer these contradictions and find a solution. The contradictions are entirely present in our lives. There is nothing contradictory, otherwise it would not have existed. Hegel said: "Contradiction is the essence of all phenomena and things and this struggle is the source of all growth."

And the things and qualities and nomenclature contradict each other each thing has its idea on which it was built, as well as the universe is based on the idea of contradiction that ensures him balance and continuity, there is night and day, and may differ or agree with similar in terms of objectives or content, this It is seen in life matters in general, and the human product through the cognitive and creative fields contains many contradictions of things, and in the field of arts, this idea varies with its cultural meaning.

There is a striking contrast between the art of heritage (Islamic art) and modern art. For example, we refer to more than one specificity that illustrates this contradiction, such as functionalism that has never been separated from Islamic art, as well as abstractism as an artistic philosophy that is derived from a comprehensive religious understanding of the world and man. And, like the abolition of the principle of simulation as a fundamental artistic principle, and the artist's subjectivity and individuality as a source of major art, and the absence of the subject.

In order to identify the idea of contradiction in the subject of research, we must identify the idea of contradiction and define it first, and then the philosophical content of the idea of contradictions on the fine arts, including the graduation of the general idea of research is the study of contradiction as aesthetic value and its impact on the art of heritage and modern art with highlighting Contradiction by analyzing artworks too. 